\title{
Review of Mathematical Programming Applications in Water Resource Management Under Uncertainty
}

\author{
Thomas W. Archibald $^{1}$ (D) . Sarah E. Marshall ${ }^{2}$ \\ Received: 30 August 2017 / Accepted: 12 July 2018 / Published online: 3 August 2018 \\ (C) The Author(s) 2018
}

\begin{abstract}
Economic development, variation in weather patterns and natural disasters focus attention on the management of water resources. This paper reviews the literature on the development of mathematical programming models for water resource management under uncertainty between 2010 and 2017. A systematic search of the academic literature identified 448 journal articles on water resource management for examination. Bibliometric analysis is employed to investigate the methods that researchers are currently using to address this problem and to identify recent trends in research in the area. The research reveals that stochastic dynamic programming and multistage stochastic programming are the methods most commonly applied. Water resource allocation, climate change, water quality and agricultural irrigation are amongst the most frequently discussed topics in the literature. A more detailed examination of the literature on each of these topics is included. The findings suggest that there is a need for mathematical programming models of large-scale water systems that deal with uncertainty and multiobjectives in an effective and computationally efficient way.
\end{abstract}

Keywords Water resource management · Mathematical programming · Climate change · Water quality · Irrigation · Water allocation

\section{Introduction}

The management of water resources has been inextricably linked to human activity and economic development throughout history. It is not surprising, therefore, that water resource management has been an important application of mathematical programming techniques since the earliest developments in the area [218]. While much progress has been made in the design of effective strategies to manage water resources, it is clear from news reports from all parts of the world that many challenges remain. Statistics compiled by the United Nations state that two thirds of the world's population live in areas that experience water scarcity for at least 1 month per year and that approximately 700 million people in 43 countries suffer water scarcity at any time [196]. Prolonged drought

Thomas W. Archibald

tarchibald@ed.ac.uk

Sarah E. Marshall

sarah.marshall@aut.ac.nz

1 University of Edinburgh Business School, Edinbrugh, UK

2 Auckland University of Technology, Auckland, New Zealand in Central America led to food shortages affecting an estimated 3.5 million people in 2016 [194]. In August 2017, severe floods following heavy rain resulted in many deaths and widespread damage in Freetown, Sierra Leone [147]. Water pricing was a prominent issue in the campaigning for the 2017 New Zealand parliamentary election [148]. In August 2017, monsoon rains resulted in seasonal floods affecting 16 million people in South Asia [16] and a tropical storm brought severe flooding to Houston, USA [146]. Against this background, it is timely to consider how recent advances in mathematical programming have been applied to water resource management and to consider the opportunities for further application of mathematical programming in the area.

Only $2.5 \%$ of the water on earth is freshwater [179] and increasing the supply of freshwater, for example by desalination, is an expensive process. Lakes and rivers account for only $0.3 \%$ of the freshwater on earth [179], but play a major role in satisfying demand for water. The pressure on these scarce resources is increasing due to many factors, including population growth, continued human migration from rural to urban areas, people's desire for higher living standards, pollution, concern for the environment and variation in natural conditions. 
Groundwater, which accounts for $30 \%$ of the earth's freshwater [179], is being used increasingly to meet demand for water. A recent United Nations report estimates that 21 of the world's 37 largest aquifers are severely over-exploited [193]. The report calls for improvements in "the design of water allocation strategies that maximise the economic and social returns, while enhancing the water productivity of all sectors" [193, p. 128]. This is an area in which the application of innovative mathematical programming methods could make an important contribution.

Uncertainty is a factor in almost every aspect of water resource management. Perhaps, most obviously, it affects the water supply due to variation in precipitation. This includes short-term natural variation, seasonal variation and longer term persistence of weather conditions, such as droughts. Water supply can also be impacted by human action, such as the diversion of natural water flows, the extraction of water from lakes and aquifers and the timing and location of wastewater release. The quality of water is also uncertain as it can be influenced by the weather as well as agriculture and other industries. Unexpected failures of water systems and pipes can also impact water supply. Similarly, uncertainty affects demand for water in many ways. For example, unpredictable factors, such as precipitation, energy prices and economic conditions can all have an impact on the demand for water. Government action, for example through environmental legislation or water taxes, can also have unexpected impacts on water resource management. Decision-makers need to account for uncertainty to devise robust strategies for the short- and long-term provision of water.

The aim of this review is to examine recent developments in the application of mathematical programming to water resource management under uncertainty. The review involves a systematic search of the academic literature to identify relevant journal articles and bibliometric analysis of the selected articles to provide insight on the methodologies applied and the issues tackled. A detailed study of four themes emerging from the literature reveals possible directions for future research.

Section 2 explains the methods used to select articles for inclusion in this review. Section 3 applies bibliometric analysis to the articles identified by the literature search. Section 4 presents a detailed discussion of four themes uncovered by the bibliometric analysis. Section 5 concludes the review with a summary of the findings and suggestions for future research areas.

\section{Methodology}

This review aims to evaluate recent literature on mathematical programming applied to water resource management under uncertainty. Search terms were selected to cover the three aspects of the focus of the study: mathematical programming, water resources and uncertainty.

With respect to mathematical programming, the intention was to keep the search broad and so the search term "program*" was used. (Note: the "*" is a wildcard which will match with any word ending, so the search includes all words which start with "program".) As the application of Markov decision processes to water resource management has a long history [218], the search ("Markov*" AND "decision-process(es)") was also used. (Note: (1) the search term "process(es)" will match with the word "process" and its plural "processes"; (2) the "_" is used to indicate that the search will match all instances, where the search terms "decision" and "process(es)" occur consecutively.)

When considering water resources, it soon became apparent that there is a large number of articles addressing issues related to scheduling hydropower and integrating hydropower with power distribution systems. The application of stochastic optimisation in this area was recently reviewed by de Queiroz [165]. Increasingly the focus of research on the modelling of hydropower systems is concerned with the operation of power systems and energy markets. For this reason, and due to the existence of a recent review article, it was decided that this study should concentrate on articles dealing with general water resource management and exclude articles that deal with hydropower systems specifically. Six search terms were used to identify articles related to water resources: the general term "water"; three terms reflecting surface water storage: "reservoir(s)", "river(s)" and "lake(s)"; and two terms reflecting relevant management issues: "flood*" and "irrigat*".

Three terms were used to identify articles that model uncertainty: "stochastic", "probabilistic" and "Markov*". Again, the inclusion of the term "Markov*" reflects the long association of Markov models and water resource management. The selected terms were intended to focus the search on models that use classical probabilistic methods. The use of other related search terms, such as "uncertain*", was investigated, but these terms were found to be too general for the purposes of this survey. For example, including "uncertain*" in the search terms increased the number of articles identified by approximately $140 \%$. However, it is important to note that the articles identified by the search terms include many articles that combine classical probabilistic methods with other approaches to modelling uncertainty, for example fuzzy sets and intervals.

The literature search was performed on 12 June 2018 using the topic search in the Web of Science Core Collection database. Web of Science was selected because it is the longest established bibliographic database, and the criteria for the inclusion of journal titles are 
transparent and reviewed regularly. The Web of Science topic search matches words in the title, abstract, keywords and "Keywords-Plus" of articles. The Keywords-Plus of an article is a set of index terms generated automatically from the titles of cited references. During the course of the analysis, the Keywords-Plus feature was not found to be a reliable indicator of the content of articles for the purposes of this review. Articles that relied on terms from the Keywords-Plus matching the search terms were examined to confirm their relevance to all aspects of the study. The analysis also revealed that, as one might expect, research published in conference proceedings is often later published in more detail as a journal article. As this could result in double counting, articles in conference proceedings were excluded.

A total of 2138 items in Web of Science matched the search criteria. Of these, 859 items were eliminated because they were published before 2010 and 76 items were eliminated because they were published in 2018 . The timespan from 2010 to 2017 was chosen for the study because it consisted of entire years and provided a sample size that seemed large enough for analysis, but not too large to prevent examination of each item. A further 225 items were eliminated because they appeared in conference proceedings. The context of the use of the search terms in the remaining 978 journal articles was then considered to ensure articles were relevant to the study. During this process, 172 items were eliminated because the occurrence of "program*" did not relate to mathematical programming (for example, computer programming or simply a reference to alternative methods), 168 items were eliminated because they did not relate to water resource management (for example, the modelling of oil reservoirs) and 152 items were eliminated because they did not relate to mathematical programming or water resource management. Finally, 38 items were eliminated because the search terms only appeared in Keywords-Plus, and further examination found that the articles were not closely related to the theme of the review. The final sample consisted of 448 journal articles.

We were surprised to find only two articles from Environmental Modeling \& Assessment in the final sample. Given that the survey covered a popular modelling approach and an issue of great importance to the environment, we expected many articles to come from this journal. More detailed analysis revealed that a possible reason for this outcome is the apparent lack of articles in this journal that use mathematical programming. A Web of Science topic search on articles published in Environmental Modeling \& Assessment during the sample period returns 154 articles matching the water resource management search terms, but only 46 matching the mathematical programming search terms (of which only 28 actually use

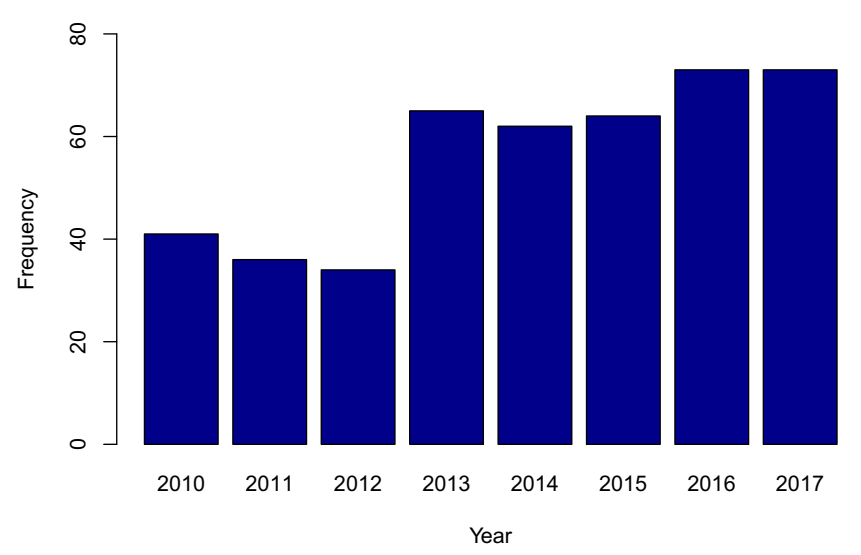

Fig. 1 Number of articles by year between January 2010 and December 2017

mathematical programming techniques) and 33 matching the uncertainty search terms. The 28 articles using mathematical programming techniques were considered for inclusion in the discussion of the themes that emerged from the bibliometric analysis.

\section{Bibliometric Analysis}

\subsection{Overview}

Bibliometric analysis involves the systematic and statistical analysis of bibliographic and citation data. The following bibliometric analysis was conducted using $R$, and made particular use of the "bibliometrix" package, developed by Aria and Cuccurullo [13].

The search terms, discussed in Section 2, resulted in the selection of 448 articles. As shown in Fig. 1, the number of articles published per year increased markedly in 2013 and has remained relatively stable over the last 5 years of the sample period.

Across the 448 articles, the journals which were published in most frequently include Water Resource Management (41 articles), Journal of Water Resources Planning and Management (34 articles) and Stochastic Environmental Research and Risk Assessment (28 articles). A list of the journals which published at least five articles in the sample is shown in Table 1. It is interesting to note that the majority of these journals focus on water or environmental research, rather than more general research areas. A notable exception to this being the European Journal of Operational Research.

Table 2 shows the most frequently cited articles within the sample. To account for the time since publication, the average number of citations per year since the year of publication was used to rank the articles. Table 2 shows the 20 articles with the highest average number of citations per 
Table 1 Titles of journals which published at least 5 articles in the sample

\begin{tabular}{ll}
\hline Journal name & Number of articles \\
\hline Water Resources Management & 41 \\
Journal of Water Resources Planning and Management & 34 \\
Stochastic Environmental Research and Risk Assessment & 28 \\
Water Resources Research & 19 \\
Agricultural Water Management & 14 \\
European Journal of Operational Research & 13 \\
IEEE Transactions on Power Systems & 13 \\
Journal of Hydroinformatics & 12 \\
Advances in Water Resources & 9 \\
Water & 9 \\
Journal of Cleaner Production & 8 \\
Journal of Environmental Management & 8 \\
Journal of Hydrology & 8 \\
Electric Power Systems Research & 7 \\
Environmental Modelling \& Software & 7 \\
Mathematical Problems in Engineering & 7 \\
Environmental Science and Pollution Research & 6 \\
Agricultural Systems & 5 \\
Journal of Irrigation and Drainage Engineering & 5 \\
\hline
\end{tabular}

year. These articles are published in 16 different journals and discuss a range of water resource management issues, including flooding, irrigation and reservoir management. As expected, a number of the most-cited articles (those marked with an ${ }^{*}$ ) are review papers.

\subsection{Practical Applications}

By extracting sequences of words starting with capital letters from the titles, abstracts and keywords of articles in the sample, a collection of proper nouns representing
Table 2 The 20 most-cited articles in the sample based on average citations per year since year of publication (note that * indicates a review paper)

\begin{tabular}{lll}
\hline Article & Number of citations & Citations per year \\
\hline Rani and Moreira [168]* & 157 & 19.6 \\
Nematian [145] & 31 & 15.5 \\
Verderame et al. [198]* $^{*}$ & 106 & 13.2 \\
Bolouri-Yazdeli et al. [23] & 51 & 12.8 \\
Fallah-Mehdipour et al. [57] & 74 & 12.3 \\
Singh [181]* & 73 & 12.2 \\
Yang et al. [219] & 43 & 10.8 \\
Wang and Huang [202] & 32 & 10.7 \\
Raje and Mujumdar [167] & 84 & 10.5 \\
Steeger et al. [184]* & 41 & 10.2 \\
Xu et al. [214] & 47 & 9.4 \\
Huang et al. [90] & 54 & 9.0 \\
Shokri et al. [180] & 44 & 8.8 \\
Grosso et al. [71] & 35 & 8.8 \\
Lu et al. [136] & 58 & 8.3 \\
Cai et al. [28] & 57 & 8.1 \\
Li et al. [123] & 64 & 8.0 \\
van Ackooij et al. [2] & 29 & 7.2 \\
Rong et al. [175] & 7 & 7.0 \\
Cai et al. [27] & 14 & 7.0 \\
\hline
\end{tabular}


Fig. 2 Number of applications relating to each country

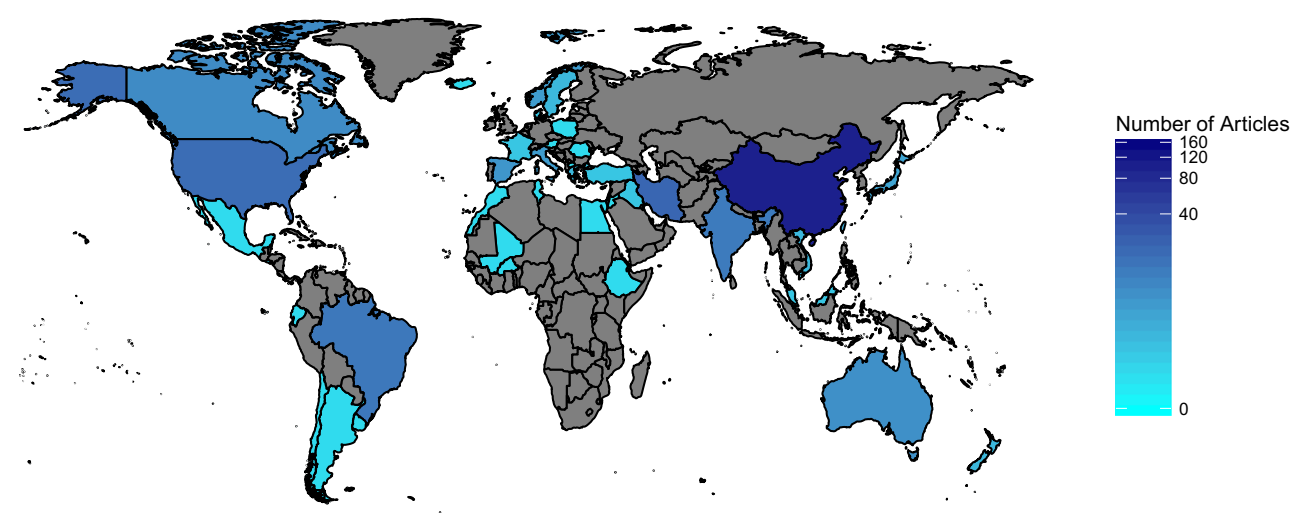

the names of countries and water systems mentioned in the articles was created. These names were examined in context to eliminate cases that do not relate to applications of the models developed in the articles (for example, the following instances would not be considered: "all revenues are in United States dollars" or "hydropower plays an important role in the Brazilian energy market"). Names were retained only where the authors state that the article uses data from a practical situation in a mathematical programming model or claim to apply a mathematical programming model to a practical situation (regardless of whether any recommendations were implemented). Based on this analysis, a total of 252 articles in the sample (56.2\%) report applying models developed for practical situations from 42 different countries and focusing on 113 different named water systems and features. Figure 2 depicts the number of articles discussing applications by country. China is the most commonly referenced country (95 articles), followed by Iran ( 21 articles), USA (18 articles) and Brazil (14 articles). Table 3 lists water systems which are modelled in two or more articles in the sample.

\subsection{Geographic Locations and Collaborations}

The country of the reprint author's affiliation was analysed to investigate patterns in the origins of articles applying mathematical programming techniques to water resource management. If no address was provided for the reprint author, then the first listed affiliation was used. The most commonly listed country was China (131 articles), followed by Canada (56 articles) and the USA (47 articles). The number of articles by country is shown in Table 4 . Figure 3 shows the geographic distribution of all listed affiliations for articles in the sample, with each country counted at most once per article. In line with numbers observed in Table 4, China is associated with the articles (160 articles), followed by Canada (108 articles), the USA (75 articles) and Iran (36 articles). The locations of the applications, discussed in Section 3.2, are displayed in Fig. 2. Comparing Figs. 3 and 2 , there is some correlation between the countries of the authors' affiliations and the application areas, with similar regions featuring in both maps.

International collaborations appear to be common within the area of water resource management, as depicted in Fig. 4. An arc between two country vertices indicates that there is at least one article in the sample, which have coauthors whose affiliations are located in those two countries. For example, within the sample of articles, authors affiliated with institutions in New Zealand have written articles with co-authors affiliated with institutions in Australia, USA and England. Within the sample of 448 articles, authors from Finland, Chile, Mexico, Poland and Romania do not have any joint publications with international co-authors in this field. If an author is affiliated with more than one institution, then the locations of all institutions are represented in the figure. However, each country is counted at most once per article. The size of each vertex corresponds to the number of articles associated with each country and the width of each edge corresponds to the number of articles with coauthors in each of the countries. For example, Canada and China have the most collaborations (65 articles), followed by China and USA (12 articles), Iran and USA ( 8 articles), and Brazil and USA (6 articles). Chinese institutions are associated with the largest number of articles in the sample (160 articles) and as such has the largest vertex, followed by institutions in Canada (108 articles), USA (75 articles) and Iran (36 articles). Note that a log scale is used to determine the vertex size and edge width.

\subsection{Keyword Analysis}

A frequency analysis was conducted to explore the appearance of words and phrases (of five or fewer words) in the article titles and keywords, and the results are summarised in Table 5. In this analysis, keyword phrases were retained as the $n$-gram stated in the article, whereas for the titles, stop words were removed and $n$-grams $(n \leq 5)$ were constructed. As expected, there is some similarity between the most commonly used words and the search terms used to select the articles, with water, 


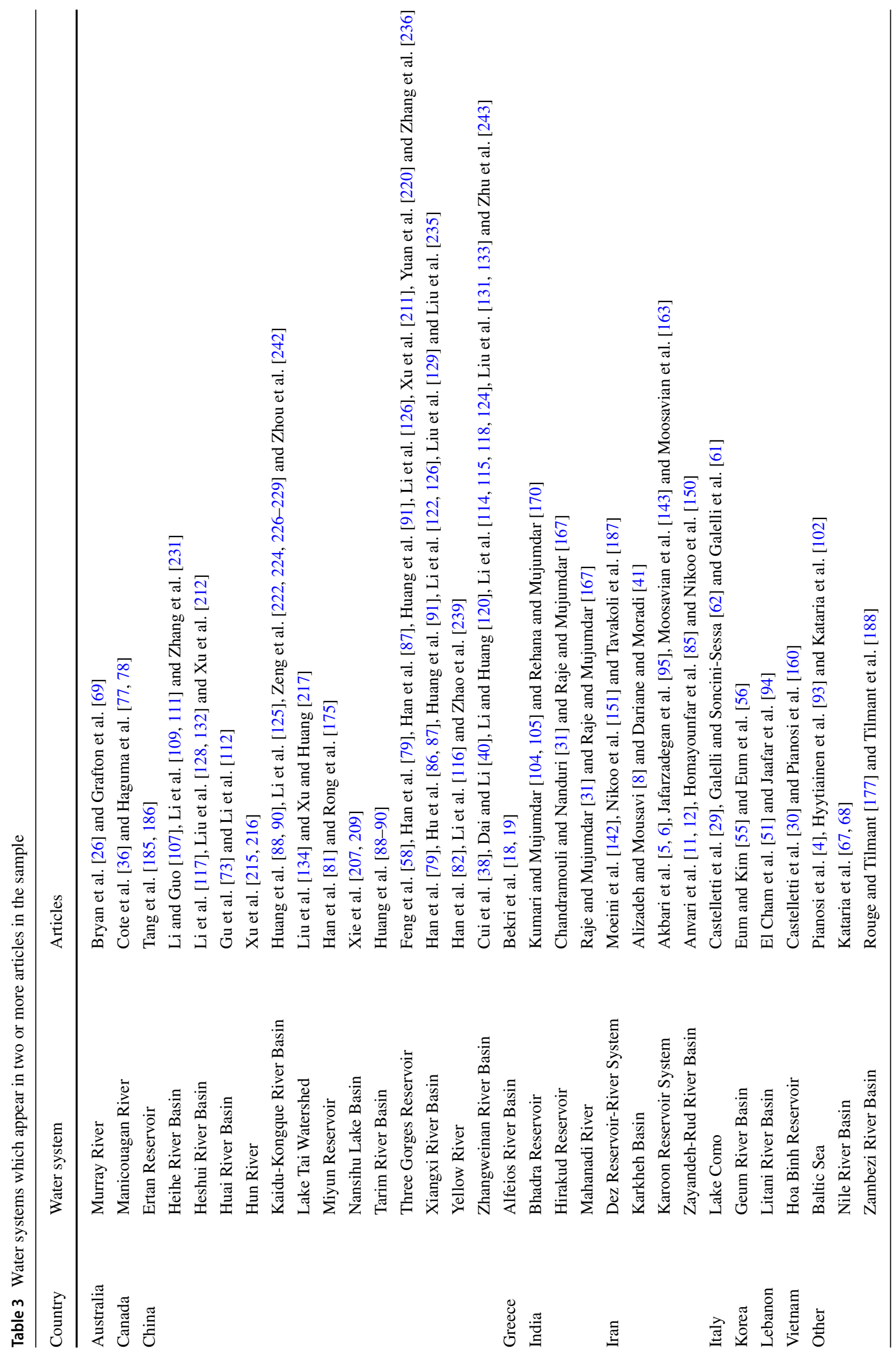


Table 4 Number of articles by country of first listed affiliation (top 10)

\begin{tabular}{ll}
\hline Country & Number of Articles \\
\hline China & 131 \\
Canada & 56 \\
USA & 47 \\
Iran & 31 \\
Brazil & 22 \\
Italy & 21 \\
Australia & 14 \\
France & 13 \\
Spain & 12 \\
India & 11 \\
Other & 90 \\
Sum & 448
\end{tabular}

stochastic and programming appearing most frequently in the titles. Interestingly, despite the fact that "uncertainty" was not included in the search terms, it is the most frequently used keyword. A number of phrases (those marked with $\mathrm{a}^{*}$ ) appear in the top 25 for both the titles and keywords. The frequencies are generally lower for keywords, as within this sample of articles authors select on average 5.16 words, whereas titles on average contain 13.57 words. Figure $5 \mathrm{a}$ and $\mathrm{b}$ depict the frequency of words and phrases within the keywords and titles respectively. The majority of the terms in both lists describe techniques (for example, "optimisation" and "stochastic programming"). Some of the terms are too general to provide any insight on the purpose of the articles (for example, "water resources" and "programming"). However, a few seem to describe issues facing decision-makers that mathematical programming might be used to address: namely "climate change", "water quality", "hydropower", "water resources allocation", "irrigation" and "reservoir operation". Four of these topics will be discussed in detail in Section 4. The other terms were not considered because hydropower is not the focus of the review.

\subsection{Type of Mathematical Programming}

The article titles were analysed to investigate the type of mathematical programming used within the sample. Titles rather than abstracts were used to ensure at most one type of programming was attributed to each article. The word "program*" appeared in 138 titles. (Note: the "**" is a wildcard, which will match with any word ending, so all words which start with "program" were included.) If "program*" did not appear in the title, but was present in the keywords, then the first occurrence of "program $*$ " in the keywords was used. This gave a total of 299 articles with "program*" in the title or keywords. Punctuation, symbols, and stop words (provided by the $R$ packages Quanteda [21]) were removed. For the selected titles/keywords, the five words preceding the word "program*" were extracted and then $n$-grams (for $n=2, \ldots, 6$, including the word "program*") were created. The most frequently occurring $n$-grams were found and those which occurred in two or more articles were included in Fig. 6. This analysis was automated; therefore, on several occasions, the word "using" was included in the $n$-grams. These nodes are coloured grey to indicate they are not part of the name of a type of mathematical programming.

As shown in Fig. 6, "stochastic programming" appeared most commonly, followed by "dynamic programming". Of the 100 articles which mentioned "stochastic programming" in their titles, there were 20 which mentioned "two-stage stochastic programming" and 5 which mentioned "inexact two stage stochastic programming". Words which appeared twice or more in the diagram were shaded in the same colour on a scale from dark green to brown/yellow, with those coloured dark green (e.g. "stochastic") appearing most frequently (8 times), those coloured brown or yellow (e.g. "mixed" and "factorial") appearing twice. Words which appeared only once in the diagram remained coloured white. Variants of multistage (including two-stage) stochastic programming feature in 39 articles. Stochastic dynamic programming (including stochastic dual dynamic programming) also features highly (63 articles). The terms

Fig. 3 Number of articles affiliated with each country

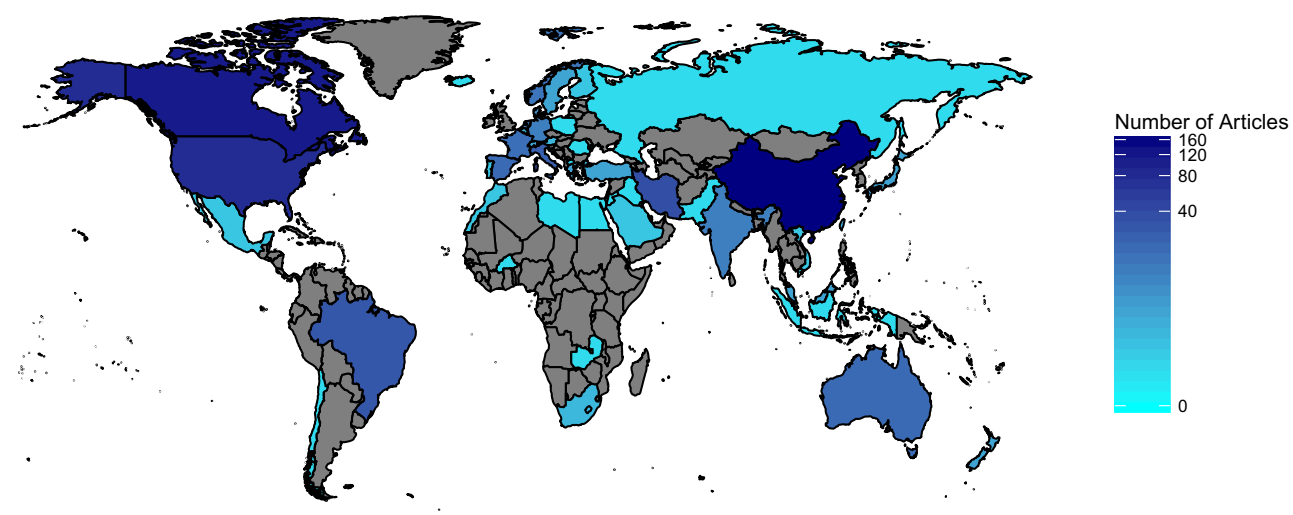


Fig. 4 International collaborations within the sample of 448 articles. Note: vertex size corresponds to number of articles affiliated with country and edge size corresponds to the number of co-authored articles

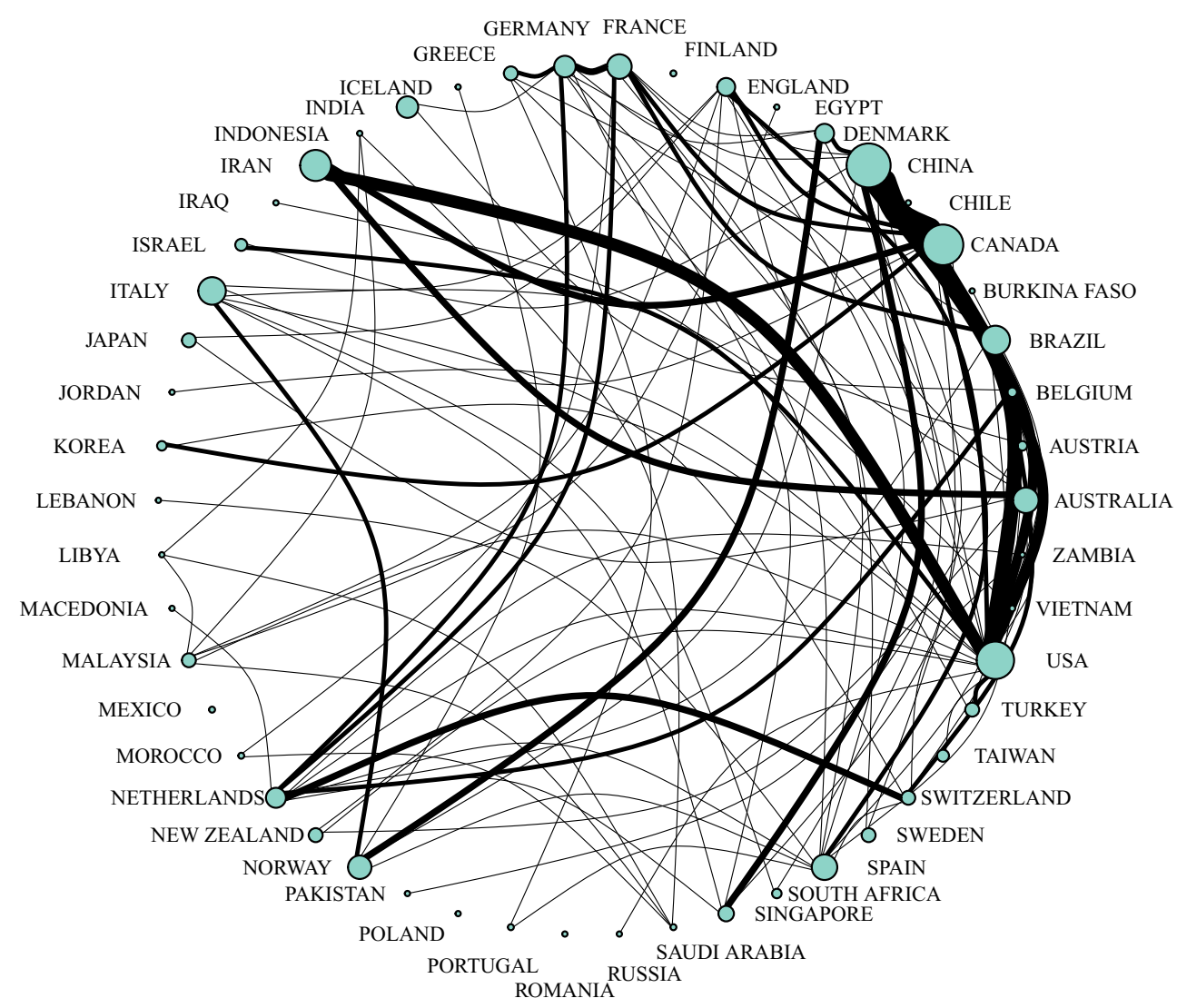

fuzzy, inexact and interval also feature often. These terms correspond to methods of dealing with uncertainty and are often combined with "stochastic". This suggests that water resource management models often involve stochastic, interval and fuzzy parameters.

Multistage stochastic programming and stochastic dynamic programming are two methodologies for sequential decision processes in which uncertainty is modelled using random variables with known probability distributions [159]. In general, multistage stochastic programming allows relatively detailed representations of the state of the process (for example, a large number of reservoirs in the water system), while stochastic dynamic programming does not due to the so-called "curse of dimensionality" [164]. On the other hand, stochastic dynamic programming generally allows more decision epochs and stochastic variables due to the exponential increase in the number of scenarios for multistage stochastic programming with these factors. Stochastic dual dynamic programming aims to combine the advantages of these methods by decomposing the problem into a number of subproblems, each of which focuses on decisions at a single epoch and approximates the expected future profit by a series of affine constraints or "cuts" [177]. However, this method is most effective for problems that can be represented as linear models. In practice, probability distributions are rarely known and so many methods have been proposed to deal with ambiguity in the probability models [159]. In this survey, the most common methods used include inexact, fuzzy and interval programming. Methods for sequential decision processes under uncertainty typically assume that the objective is to optimise a single performance measure (for example, cost or profit). However, often decision-makers are concerned about a range of performance measures and so methods to deal with multiple objectives have also been proposed [76].

\section{Emerging Themes}

\subsection{Water Allocation}

A recurring theme in the literature on water resource management is the difficulty of allocating water to multiple competing users in a way that is sustainable and satisfies the needs of growing populations, supports economic development and protects the environment. The importance of this issue is underlined in a recent United Nations report, which states that the "allocation of water resources ...to different economic sectors will largely dictate the growth potential for high quality jobs at country and local levels" [193, p. 8]. Wang and Huang [201] illustrate the issues using a hypothetical example in which water 
Table 5 Number of articles using words/phrases in titles and keywords (top 25)

\begin{tabular}{|c|c|c|c|c|c|}
\hline \multicolumn{3}{|l|}{ Sorted by keyword frequency } & \multicolumn{3}{|l|}{ Sorted by title frequency } \\
\hline Word/phrase & Keyword frequency & Title frequency & Word/phrase & Keyword frequency & Title frequency \\
\hline Uncertainty* & 123 & 66 & Water & 7 & 210 \\
\hline Stochastic programming* & 53 & 35 & Stochastic* & 15 & 133 \\
\hline Optimisation* & 48 & 77 & Programming* & 12 & 127 \\
\hline Stochastic dynamic programming & 28 & 19 & Management* & 11 & 123 \\
\hline Water resources management* & 27 & 39 & Model & 1 & 97 \\
\hline Water resources* & 26 & 76 & Optimisation* & 48 & 77 \\
\hline Dynamic programming* & 21 & 30 & Resources & 3 & 77 \\
\hline Decision-making & 19 & 4 & Water resources* & 26 & 76 \\
\hline Reservoir operation & 17 & 22 & Uncertainty* & 123 & 66 \\
\hline Climate change & 16 & 17 & Optimal & 1 & 55 \\
\hline Stochastic* & 15 & 133 & Reservoir & 6 & 55 \\
\hline Two-stage stochastic programming & 15 & 12 & Operation & 3 & 53 \\
\hline Stochastic dual dynamic programming & 13 & 7 & System & 1 & 51 \\
\hline Water quality & 13 & 15 & Two-stage* & 9 & 45 \\
\hline Programming* & 12 & 127 & Inexact & 2 & 44 \\
\hline Management* & 11 & 123 & Planning* & 11 & 44 \\
\hline Planning* & 11 & 44 & Dynamic & 3 & 40 \\
\hline Water resources allocation & 11 & 13 & Resources management & 1 & 39 \\
\hline Chance-constrained programming & 10 & 3 & Water resources management* & 27 & 39 \\
\hline Hydropower* & 10 & 29 & Irrigation* & 10 & 37 \\
\hline Irrigation* & 10 & 37 & Fuzzy* & 7 & 35 \\
\hline Two-stage* & 9 & 45 & Stochastic programming* & 53 & 35 \\
\hline Chance constraints & 7 & 1 & Uncertainties & 1 & 33 \\
\hline Fuzzy* & 7 & 35 & Dynamic programming* & 21 & 30 \\
\hline Markov decision processes & 7 & 4 & Hydropower* & 10 & 29 \\
\hline
\end{tabular}

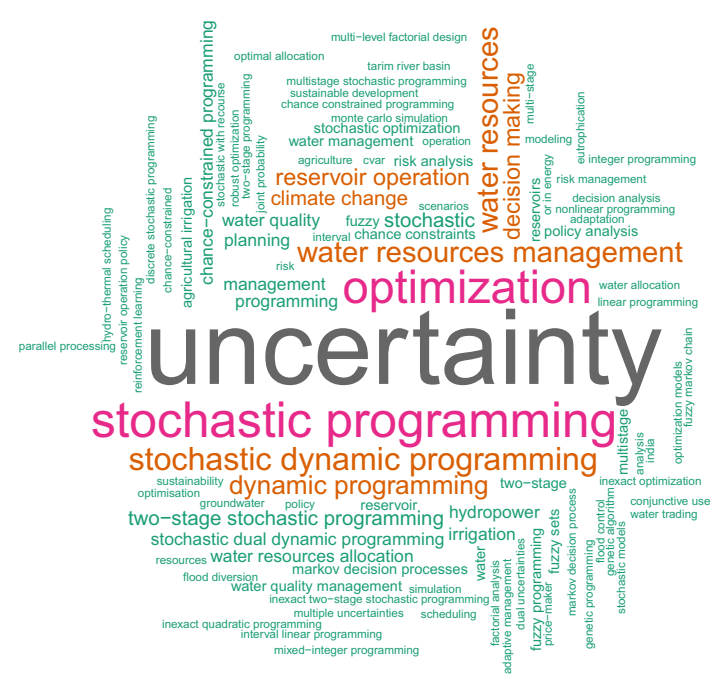

(a) By Keywords

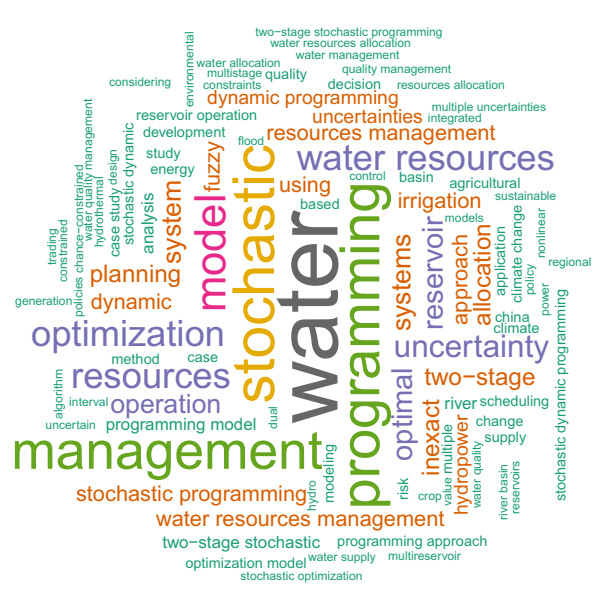

(b) By Title (including 5-grams)

Fig. 5 Word clouds depicting frequency of words and phrases in the article titles and keywords 
Fig. 6 Type of mathematical programming used in titles and keywords. Node colour represents frequency of words in diagram; dark green represents most frequent, yellow/brown represents least frequent

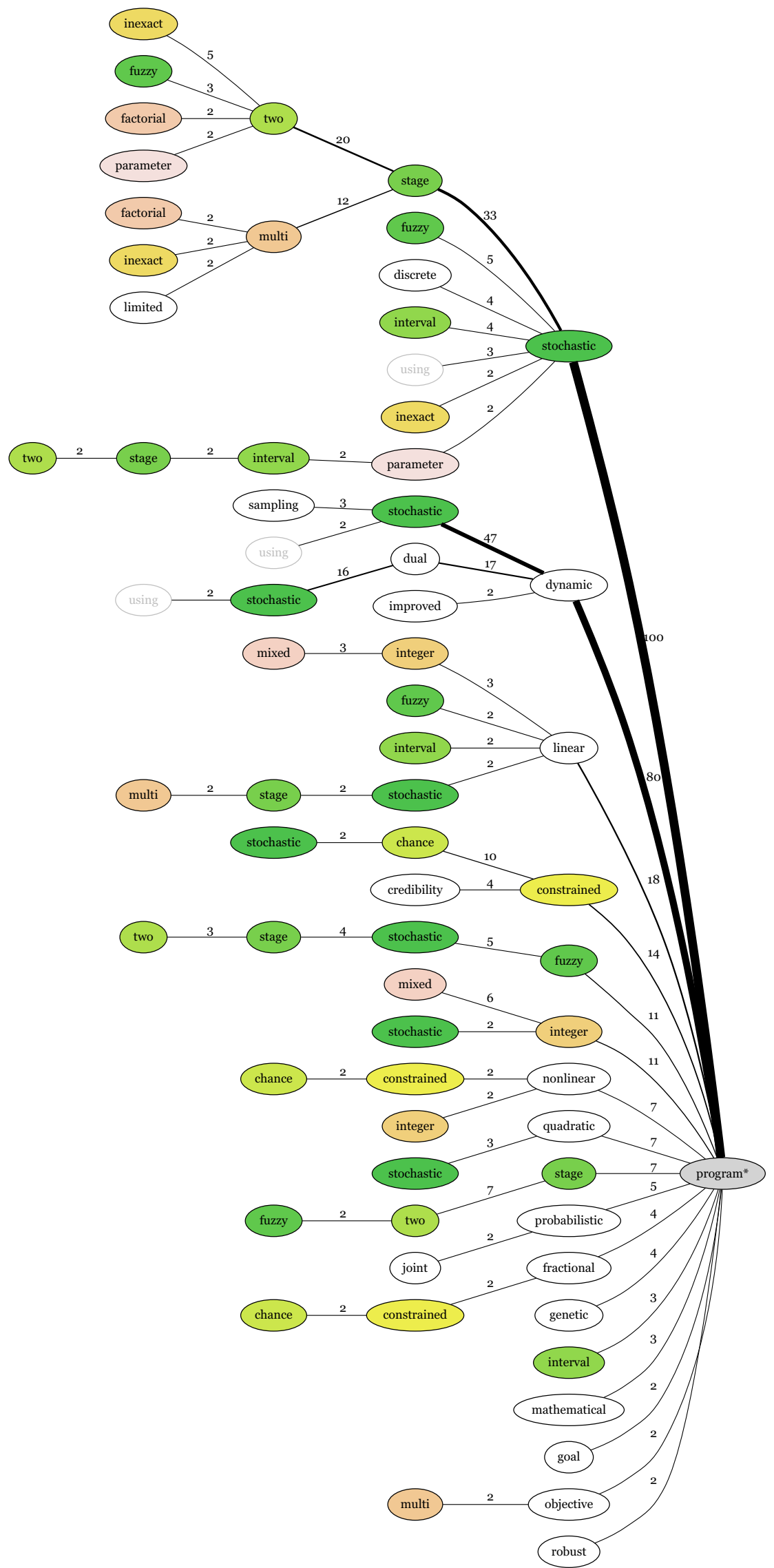


from a single reservoir has to be allocated for industrial use, agricultural use and municipal water supply over a multiperiod planning horizon. Target releases are set in advance for planning purposes, and deviations from the target releases are penalised. Due to uncertainty in water supply, decision-makers face the risks of system failure, due to the inability to meet target allocations, and missed opportunity, due to conservative planned allocations. Using interactive multistage stochastic fuzzy programming, Wang and Huang [201] maximise the benefit of the water allocation subject to the decision-maker's tolerance of constraint violation.

Incorporating the risk of constraint violation is the most common approach to the problem of allocating scarce water resources for multiple uses under uncertainty. A chance constraint programming model includes groups of constraints, which do not need to be satisfied in all possible future scenarios. Decision-makers specify the probabilities with which constraints are satisfied individually $[74,75$, $108,110,135,171,172,203,234]$ or jointly $[72,73$, $119,137,228,231,244]$. Closely related to this approach, Dong et al. [44] propose a stochastic programming model with two objectives: maximising system benefits and maximising the probability that the constraints are satisfied. For cases in which the constraint coefficients are expressed as fuzzy numbers, this concept is adapted by the introduction of a credibility measure. In credibility constrained programming, the "credibility" that a constraint is satisfied must reach a specified threshold [130, 199, $212,222,223]$. The models developed are generally illustrated using hypothetical examples or cases inspired by real applications of water resource management. However, there is little evidence of the impact of the research on decisions taken by managers or policy-makers. In some cases, shortcomings in the existing policies are highlighted and improvements are proposed. Zeng et al. [228] apply the model developed to the Tarim River Basin, China and find that demand for water in the region already exceeds the sustainable capacity of the water system. They use the model to support an argument in favour of water trading as an effective way to manage water resources in the region.

Many models of water resource allocation problems assume that the benefits from all types of water use can be expressed in monetary terms and focus on the objective to maximise monetary value. This is not always appropriate particularly given the importance of water to the environment and the scarcity of water resources in many regions. There is a need for efficient and sustainable water allocations to support economic development. Fractional programming has been proposed as a method for striking a compromise between the conflicting goals of maximising the benefit from the exploitation of water resources and sustainable water resource management [38, 108, 171, 172].
Generally, in a fractional programming model for water resource management the objective is to maximise the ratio of the benefit from water use and water consumption. $\mathrm{Li}$ et al. [108] also consider the ratio of the benefit from water use and water shortages (for example, for domestic and environmental uses). Cui et al. [38] apply fractional programming to the management of water for agricultural uses in the Zhangweinan River Basin, China. They argue that the model provides insight on the trade-off between the economic benefits and system reliability, which helps to support sustainable water resource management.

The multiobjective nature of the water allocation problem is rarely modelled explicitly. Tilmant et al. [188] use stochastic dual dynamic programming to examine the tradeoff between hydropower production and ecological preservation without imposing a monetary value on the latter. Chang et al. [32] develop a multiobjective mathematical programming approach for the problem of choosing the size of a new reservoir to ensure requirements for water supply, water quality and environmental restoration are met. Pianosi et al. [160] propose a multiobjective Markov decision process model, which seeks to maximise an arbitrary weighted sum of the different objectives. Reinforcement learning is used to approximate the Pareto frontier. Davidsen et al. [42] balance conflicting objectives by maximising economic benefit subject to constraints on water consumption and water quality. The model is proposed to address issues of water scarcity and water quality in the North China Plain. Ren et al. [172] combine fractional, chance-constrained and goal programming to allocate water to three industrial sectors in a way that balances social benefits (measured by employment), profits and water consumption.

\subsection{Climate Change}

The effects of climate change are wide-ranging and in the context of water resource management, potential impacts include rising sea-levels [15], climate variability [20], extreme rainfall events [15], natural disasters, such as flooding [53], agricultural productivity [47], increased uncertainty [170, 182] and availability of and demand for water [170]. The impact of climate change will vary across locations. In the Iberian Peninsula, for example, climate change is expected to affect hydropower production through changes to rainfall, the demand for electricity due to temperature changes and irrigation requirements due to changing rainfall and temperatures [156]. In the Manicouagan River, Quebec, Canada, on the other hand, climate change is expected to lead to increased annual inflows, reduced spring peak flow and earlier spring floods [77].

It is clear that climate change is an important consideration in water resource management. The impact of climate 
change has been discussed in the context of reservoir management $[14,37,58,60,77,78,167]$, renewable energies, including hydropower generation $[14,77,78,156,161,166$, 167], agriculture [45], irrigation [10, 20, 46, 47, 49, 83, 100, 109, 167], changing rainfall patterns [7, 49], investment planning in transportation and roadways [15] and water resource management [200].

A variety of mathematical programming techniques have been employed to either study the effect of, or incorporate the uncertainty caused by, climate change in water resource management. These techniques include stochastic programming $[15,20,45-47,49,100,109,127$, 200], dynamic programming including stochastic dynamic programming $[14,53,58,60,77,78,83,156,162,167,182]$ and nonlinear programming [10]. Specialist software tools have also been developed, including a MATLAB toolbox [66].

The uncertainty of climate variables like rainfall, stream flows, water usage and temperature have been modelled in a variety of ways, including probability distributions [45, 47, 162], interval programming [109, 200], fuzzy methodologies [109], and in some cases a combination of approaches. Other papers generate climate scenarios using general circulation models [14] and regional atmospheric modelling systems [45]. The impact of climate variables on the ecosystem has been modelled using the soil and water assessment tool (SWAT) [77] and the environmental policy integrated climate model (EPIC) [83].

Rainfall is a key source of irrigation water for farmers. Climate change is likely to impact the amount of rainfall and may also lead to increased variability in rainfall. This increases the importance of accurate rainfall prediction, a topic studied by Ozmen et al. [153]. Climate change is likely to result in increased uncertainty and shortages of surface water necessitating the use of groundwater [10]. Dono and Mazzapicchio [49] studied historical rainfall data in the Mediterranean and found decreasing annual rainfall and increasing monthly variability of rainfall. They studied the impact of rainfall changes to the amount of water accumulated for irrigation for a variety of farm types.

Climate change has prompted increased investment in renewable energy technologies, such as hydropower; however, in many cases, these technologies rely on favourable climatic conditions [166]. Hydropower systems, for example, are influenced by reservoir levels and stream inflows, which are in turn influenced by factors, such as rainfall [37, $58,78,166]$. Effective management of the natural resources, such as reservoirs, under changing climatic conditions is therefore important for the success of these renewable energies, and as such, has been widely discussed in the literature. Raje and Mujumdar [167] explore the impact of climate change on a reservoir in relation to hydropower, irrigation and flood control, under different future climate scenarios. The trade-offs between maintaining reliability of power generation (through hydropower), irrigation (especially in the case of increased droughts) and flood control are explored. Using a stochastic dynamic programming model with the objective of maximising reliability, they found that reliability of hydropower can be increased; however, this may require a lower reliability of irrigation and flood control. Arsenault et al. [14] also use stochastic dynamic programming; however, rather than aiming to maximise reliability, they explore the impact of both structural (e.g. building new turbines) and non-structural (e.g. optimising reservoir management) changes on reservoir operations under a scenario of increased water flows due to climate change.

Incorporating climate information into investment planning and long-term decision-making related to water resource management is investigated by Fernandez et al. [59]. The value of incorporating climate-related information has been studied in the context of the impact of El Nino on Taiwanese water markets [127], improving reservoir management through more accurate inflow forecasts [64] and the optimal height of dikes given predicted changes in sea levels [162]. The impact of policies and legislation, such as European Water Framework Directive, in investment planning has also been explored [48, 83]. Heumesser et al. [83] compare investment into two irrigation systems and the impact of subsidies on this decision. Kahil et al. [100] explore the impact of climate change and two policy interventions (water markets and subsidies) on irrigation in southern Europe. There may often be trade-offs between short-term economic gains and long-term sustainability [20]. This suggests that policy interventions, such as subsidies, may be necessary in some water resource applications in order to encourage investment in long-term sustainable solutions.

\subsection{Water Quality}

Access to good quality water is vital for all aspects of human life, including the provision of sanitation, hygiene and health, sustainable social and economic development, and the protection of the environment. This is highlighted by the integral role of water in all eight of UN's Millennium Development Goals (MDPs) [191]. Great improvements have been made in the past decades with an additional 1.2 billion people gaining access to piped water supplies and an additional 0.4 billion gaining access to non-piped water supplies between 2000 and 2015 [205] and advances in sanitation for 2.1 billion people since 1990 [195]. However, access to safe and clean water continues to be an issue. A 2012 report commissioned by the WHO/UNICEF Joint Monitoring Programme for Water Supply and Sanitation estimated that 1.8 billion people use a source of drinking water which is faecally contaminated [204]. Poor water 
quality disproportionately affects women and children [192], so continued improvements in access to clean water and sanitation are an important part of the journey towards equality.

Water quality can be affected by both point sources (e.g. pipes and drains) and non-point sources (e.g. urban land use, agriculture, forestry, eutrophication) [52]. Point and non-point sources of pollution are often regarded as controllable [139]); however, other factors, such as the weather and climate, can also impact water quality [50]. On a global scale, water quality can be assessed using measures, such as the proportion of the population with sustainable access to an improved water source [190]. However, for a particular water source, water quality typically involves the measurement of components, such as total phosphorus and total nitrogen [129], biological oxygen demand [33, 42, 129], chemical oxygen demand [132, 139, 141], dissolved oxygen [139] and Escherichia coli [33]. The impacts of pollution on water sources have been modelled by tools, such as the Streeter-Phelps equation [121] and the Soil and Water Assessment Tool (SWAT) [63]. For example, the SWAT has been used to obtain protocols for water quality [235], and to explore the impacts of nitrogen runoff, fertiliser application rates and crop yields [241].

As populations increase, the strain on the world's water resources is only going to increase; therefore, effective strategies for the management of water quality are needed. Techniques such as mathematical programming have played, and will continue to play, a role in the development and assessment of these strategies. Within the mathematical programming literature, water quality has been considered in a variety of contexts, as shown in Table 6 . These contexts are clearly not mutually exclusive. The range of contexts shown in Table 6 demonstrates that considering water quality is important in almost all aspects of water resource management.

A variety of mathematical programming techniques have been applied to address the issue of water quality, directly (e.g. where the objective is to improve quality [139] or to minimise the risk of poor quality [65]) or indirectly (e.g. where the solution is constrained by and must adhere to quality targets [17, 42, 91]). The mathematical programming techniques applied in this research include linear programming [80, 103, 178, 197], nonlinear programming [17, 91, 121, 150, 155, 206], dynamic programming [138, 174, 241], stochastic programming $[33,42,70,99,128,139,141,187,207,208$, $224,225,240]$, and quadratic programming $[86,113]$.

The highly interconnected and interdependent nature of hydrological systems, the desire to balance social, economic and environmental factors and the inherent uncertainty associated with such systems, often lead to complex models [121, 213]. The implementation of long-term models, particularly those which are nonlinear and include uncertainty can be limited by the computational burden associated with solving such models [150]. A traditional approach for modelling parameter uncertainty within a model is to use probability distributions [102]; however, the complexity of hydrological models can make estimation of these distributions difficult $[201,213]$. The computational burden of stochasticity and the difficulty of parameter estimation have been addressed in a number of ways including, interval programming [86, 99, 150, 217], inexact programming [86, 113, 126, 208], possibilistic and fuzzy methodologies [99, 128, 224, 225, 235, 237], and constraint flexibility [206]. Some authors have used a combination of these techniques. For example, Li et al. [126] develop an inexact two-stage stochastic credibility constrained programming model, which deals with uncertainty through probability distributions, intervals and fuzzy membership functions.

The release of wastewater from domestic, commercial, industrial and agricultural uses is a major factor in water quality management, particular given that globally $80 \%$ of wastewater is not treated before release [195]. The development of a circular economy in which water is reused and recycled will be key to ensuring sustainability, and this will require effective management strategies at the four stages of the wastewater management cycle: pollution reduction, wastewater collection and treatment, reuse of wastewater, recovery of useful by-products [195]. Within the mathematical programming literature, various aspects of wastewater management have been considered, including pollution reduction $[39,43,134,175]$, water treatment [33, 206], and the reuse of wastewater [98, 106, 169, 219, 238]. The call for a circular economy motivates further research, particularly in the areas of wastewater reuse and by-product recovery, which are unrepresented in the literature.

Improving or maintaining water quality is often considered alongside other objectives, such as minimising cost and maintaining water supply targets. This often requires a trade-off between environmental and economic factors [132, 230, 237] and can be further complicated by the fact that successful water quality management requires individuals and organisations to act in the collective interest [195]. For this reason, legislation, such as the European Water Framework Directive (WFD), is incorporated into water quality management models. Pena-Haro et al. [155] study a minimum cost fertiliser plan, subject to the water quality requirements of the European WFD. Gren [70] explores the impact of the European WFD water quality targets on the cost-effectiveness policies for nutrient management. Marinoni et al. [140] propose a framework for planning major investment decisions and apply this to the case of a water quality enhancement program in a river catchment in Brisbane, Australia. Compromise programming is first used to score the options 
Table 6 Contexts in which water quality has been considered

\begin{tabular}{ll}
\hline Context & Articles \\
\hline Agriculture & {$[3,50,122,138,155,210,217,224,237]$} \\
Ballast water & {$[93,99,101,149]$} \\
Biofuel production & {$[241]$} \\
Chlorination management & {$[103]$} \\
Climate change & {$[70]$} \\
Effluent trading & {$[122,235]$} \\
Eutrophication management & {$[4,91,102,178]$} \\
Groundwater management & {$[155,183]$} \\
Marine Environments & {$[154]$} \\
Reservoir/river/stream management & {$[42,87,118,121,126,132,139,150,174,176,208,213,224]$} \\
Storm water & {$[17]$} \\
Wastewater & {$[1,33,65,80,86,98,106,113,129,139,141,169,187,197,206,219,238]$} \\
Water allocation & {$[172,230,233]$} \\
Water trading & {$[224]$} \\
Water treatment & {$[33,206]$} \\
Wetlands & {$[39,207,225]$} \\
\hline
\end{tabular}

for pollution reduction at various sites and the optimal investment problem is then formulated as a multicriteria knapsack problem. In some cases, legislation needs to be considered alongside other management strategies. For example, Li, and Huang [121] found that a trading-based scheme worked more effectively than regulations, Jayet and Petsakos [97] and Bourgeois et al. [24] consider the use of a nitrogen tax under different policy scenarios, and Zhou et al. [241] explored the impact of two types of subsidies for the production of biofuel and water quality improvement.

\subsection{Agricultural Irrigation}

It is widely reported that agricultural irrigation is responsible for nearly $70 \%$ of global water use and that the area of land under irrigation continues to increase in many regions to help meet the demands of growing populations [22, 109]. Irrigation planning is a challenging problem due to factors, such as uncertainty in agricultural commodity prices, the need for an equitable allocation of irrigation water to all users in a region and demands for water for other uses. The problem is compounded by the fact that instances of lower than average water supply often coincide with higher than average need for irrigation. A wide range of mathematical programming techniques have been applied, individually and in combination, to support irrigation planning including multistage stochastic programming (28\% of articles on irrigation in the sample including [34, 54, 173]), stochastic dynamic programming $(25 \%$ of articles on irrigation in the sample including $[12,22,158])$, inexact programming, including fuzzy and interval-based programming, (36\% of articles on irrigation in the sample, for example $[35,105$,
152]) and nonlinear programming (14\% of articles on irrigation in the sample including $[10,25])$. The problem has been studied at various levels ranging from the farm level $[22,83,92]$ to the level of a large water system or country [107, 144, 221].

Zhang et al. [232] focus on the challenge of modelling variations in system conditions over time, for example due to seasonal variations. By combining multistage stochastic programming, chance constraint programming and fractional programming, a model is developed for the Heihe River Basin, China. Chen et al. [35] also examine seasonal variations in system conditions. The model they propose uses multistage stochastic programming and interval programming to plan inter-seasonal and intraseasonal water allocation to multiple irrigation areas and non-agricultural uses. Li et al. [116] emphasise the complexity of irrigation management due to, for example, the response of crops to water at different stages of development and the water cycle in irrigation systems. They argue that prior research fails to address such factors adequately. Using fuzzy stochastic programming, a model that reflects the field water cycle is developed. Results based on data from the Yellow River Basin, China suggest that the model leads to a more efficient allocation of irrigation water in arid regions with shallow groundwater. Recent research on irrigation systems appears to pay more attention to the complexity of the underlying processes, for example the water requirement of crops at different growth stages [12, 231].

Access to water for agricultural irrigation is often considered a right that may be associated with land ownership [124]. While this situation is changing in some regions, such 
as the Murray-Darling Basin, it remains a barrier to effective water resource management in many regions [124]. Where agricultural irrigation has a preferential claim on available water, the economy of a region may suffer due to a lack of water for other uses, such as urban development and electricity generation. Agricultural irrigation may involve the use of surface water, groundwater or the conjunctive use of surface water and groundwater [9]. Both sources of irrigation water can have negative environmental impactsurface water, for example, due to variability in river flow [69] and groundwater extraction, for example, through salt water intrusion and subsidence [133]. Models to support irrigation planning need to consider environmental factors and broader economic issues. It is often argued that the models developed for irrigation planning provide decision-makers with insights on the trade-offs between environmental sustainability, economic development and the benefits of irrigation [74]. However, more research addressing these tensions explicitly is required. Grafton et al. [69] propose a stochastic dynamic programming model of a general river system and apply it to the Murray-Darling Basin, Australia. The model assesses the trade-off between diversions for agricultural irrigation and river flow to sustain the environment. The model provides evidence that periodic controlled floods provide net benefits to society because diminishing returns from the use of irrigation water, as well as the existence of water markets, mitigate the costs of increased environmental flows and lower water diversions. Pereira-Cardenal et al. [157] analyse a stochastic dual dynamic programming model of a mixed energy and irrigation system on the Iberian Peninsula. The system includes river basins with high hydropower productivity and low value irrigation use, and others with low hydropower productivity and high value irrigation use. The results suggest that current water allocations to hydropower and irrigation are suboptimal, because they do not accurately reflect the relative benefits of the uses of water.

Models of agricultural irrigation often consider the impact of drought on decision-making. Torres et al. [189] emphasise the need to distinguish between precipitation and irrigation water. In arid regions, where crops might rely entirely on irrigation, the assumption that water from all sources can be aggregated in models may be reasonable. However, Torres et al. [189] argue that most irrigation systems supplement precipitation, and so irrigation models should consider precipitation and irrigation water separately. Torres et al. [189] use mathematical programming to show that the cost of drought can be underestimated substantially by models ignoring this issue. Ho et al. [84] use stochastic programming to provide insight on the use of irrigation water during extreme water shortages. The optimal actions are shown to depend on the drought duration.
Grafton et al. [69] include the drought status as a state variable in a model of irrigation management to allow the persistence and cost of drought to be considered.

Reflecting a growing interest in pricing strategies for water resource management, several recent studies have examined the design and impact of water pricing and water markets on irrigation planning. Bozorg-Haddad et al. [25] use nonlinear programming to estimate farmers' willingness-to-pay for irrigation water. Heumesser et al. [83] use stochastic dynamic programming to examine the impact of volume-based water pricing on farmers' investment in irrigation systems. Based on data that is characteristic of a semi-arid region in Austria, Heumesser et al. [83] show that the decision to invest in costly water-efficient irrigation systems is not affected by water pricing. Water pricing is shown to result in lower use of irrigation systems, which may have benefits for water resource management generally, but results in lower crop yields. In contrast, Bhaduri and Manna [22], also using stochastic dynamic programming, find that a flexible (demand-dependent) water price can result in a substantial increase in the adoption rate of efficient irrigation systems. Analysis of the model suggest that the adoption rate is even higher when farmers are also able to invest in water storage and when the water supply is more variable.

Kahil et al. [100] and Rey et al. [173] use two-stage stochastic programming to explore the potential impact of water markets using data from two different irrigation districts in Spain. Rey et al. [100] use their model to support the argument that the development of efficient water markets is more beneficial to industry and society than subsidies to improve irrigation infrastructure. Rey et al. [173] assess the value of an option contract, which allows the holder access to an additional flexible water source when the regular supply is below an agreed threshold. The model developed is used to illustrate the potential benefits of using option contracts rather than relying on additional purchases from the water market. Li et al. [124] use fuzzy stochastic programming and data relating to the Zhangweinan River Basin, China to explore the benefits of water markets for irrigation planning. Water trading is shown to allow excess irrigation water to be reallocated, while maintaining agricultural revenues, provided trading costs are not too high. Jansouz et al. [96] investigate the impact of water trading on the release of water from Voshmgir Dam, Iran. They show that water trading results in more effective water use with similar agricultural profit, but it reduces the land under irrigation and, hence, the number of farmers. So far, the potential benefits of water trading have not been realised in practice because there are few regions with a sufficiently developed water market to support the trading mechanisms $[100,124,173]$. 


\section{Conclusions}

The review has confirmed that the application of mathematical programming to water resource management under uncertainty remains an important research area. Much of the research in this area employs techniques that are related to multistage stochastic programming or stochastic dynamic programming. Often modelling the uncertainty inherent in water resource management problems is difficult due to the lack of suitable data and the computational complexity. Therefore, many of the proposed mathematical programming techniques combine stochastic models of problem parameters with interval and fuzzy models. Climate change is a major source of uncertainty in water resource management problems, particularly for long-term decision-making. Water resource management generally involves satisfying competing demands for water. Mathematical programming models with chance constraints are often used as a way to manage the trade-offs between the different water uses.

Bibliometric analysis shows that researchers in water resource management and applications of water resource management are distributed widely throughout the world. While the location of authors is consistent with recent trends in academic publishing, there is also a clear correlation between the location of authors and regions facing particular issues with water resource management. A recent report noted that $50 \%$ of the people facing water scarcity for at least 1 month per year live in China and India [195], which might contribute to the relatively high frequencies of authors and applications in these countries. Hydropower, which represents a substantial proportion of electricity production in Brazil, Canada and Norway, might also contribute to the correlation. Four themes emerged from the bibliometric analysis: the equitable allocation of scarce water resources to users, the impact of climate change on water resource management, ensuring wide access to supplies of good quality water and the management of agricultural irrigation. These are likely to be important topics for future research on water resource management.

Stochastic dual dynamic programming is a common solution method for multistage stochastic programming applied to the scheduling of hydropower systems [165]. Despite the prevalence of multistage stochastic programming in the articles reviewed, relatively few articles employed the stochastic dual dynamic programming approach. This suggests that there might be scope for greater application of stochastic dual dynamic programming to general water resource management problems.

Many of the articles reviewed discuss practical applications and many of the articles claim to develop models that could help develop effective strategies for water resource management. Despite this, few of the articles reviewed report on the practical use of the models developed or discuss practical issues relating to the implementation of the recommendations. It seems that more work is required to bring academic researchers and practitioners closer together to address the challenges of water resource management.

The United Nations and other organisations have highlighted the challenges facing decision-makers with responsibility for water resource management [192, 194, 195]. Many of these challenges involve large water systems, great uncertainty and multiple objectives. There is a need for research to develop effective and computationally efficient mathematical programming methods to address these problems and, hence, help decision-makers design sustainable strategies for water resource management that maximise the economic and social benefits.

Open Access This article is distributed under the terms of the Creative Commons Attribution 4.0 International License (http:// creativecommons.org/licenses/by/4.0/), which permits unrestricted use, distribution, and reproduction in any medium, provided you give appropriate credit to the original author(s) and the source, provide a link to the Creative Commons license, and indicate if changes were made.

\section{References}

1. Aasgard, E.K., Andersen, G.S., Fleten, S.E., Haugstvedt, D. (2014). Evaluating a stochastic-programming-based bidding model for a multireservoir system. IEEE Transactions on Power Systems, 29(4), 1748-1757. https://doi.org/10.1109/ TPWRS.2014.2298311.

2. van Ackooij, W., Henrion, R., Moeller, A., Zorgati, R. (2014). Joint chance constrained programming for hydro reservoir management. Optimization and Engineering, 15(2), 509-531. https://doi.org/10.1007/s11081-013-9236-4.

3. Affuso, E. (2017). The environmental impact of El Nino southern oscillation forecasts. Tropical Agriculture, 94(1), 31-41.

4. Ahlvik, L., \& Hyytiainen, K. (2015). Value of adaptation in water protection - economic impacts of uncertain climate change in the Baltic Sea. Ecological Economics, 116, 231-240. https://doi.org/10.1016/j.ecolecon.2015.04.027.

5. Akbari, M., Afshar, A., Mousavi, S.J. (2011). Stochastic multiobjective reservoir operation under imprecise objectives: multicriteria decision-making approach. Journal of Hydroinformatics, 13(1), 110-120. https://doi.org/10.2166/hydro.2010.012.

6. Akbari, M., Afshar, A., Mousavi, S.J. (2014). Multi-objective reservoir operation under emergency condition: Abbaspour reservoir case study with non-functional spillways. Journal of Flood Risk Management, 7(4), 374-384. https://doi.org/10.1111 /jfr3.12061.

7. Alam, M.S., \& Elshorbagy, A. (2015). Quantification of the climate change-induced variations in Intensity-DurationFrequency curves in the Canadian Prairies. Journal of Hydrology, 527, 990-1005. https://doi.org/10.1016/j.jhydrol.2015.05.059.

8. Alizadeh, H., \& Mousavi, S.J. (2013). Coupled stochastic soil moisture simulation-optimization model of deficit irrigation. Water Resources Research, 49(7), 4100-4113. https://doi.org/10 1002/wrcr.20282.

9. An-Vo, D.A., Mushtaq, S., Nguyen-Ky, T., Bundschuh, J., Tran-Cong, T., Maraseni, T.N., Reardon-Smith, K. (2015). 
Nonlinear optimisation using production functions to estimate economic benefit of conjunctive water use for multicrop production. Water Resources Management, 29(7), 2153-2170. https://doi.org/10.1007/s11269-015-0933-y.

10. An-Vo, D.A., Mushtaq, S., Reardon-Smith, K. (2015). Estimating the value of conjunctive water use at a system-level using nonlinear programing model. Journal of Economic and Social Policy, 17, 2.

11. Anvari, S., Mousavi, S.J., Morid, S. (2014). Sampling/stochastic dynamic programming for optimal operation of multi-purpose reservoirs using artificial neural network-based ensemble streamflow predictions. Journal of Hydroinformatics, 16(4), 907-921. https://doi.org/10.2166/hydro.2013.236.

12. Anvari, S., Mousavi, S.J., Morid, S. (2017). Stochastic dynamic programming-based approach for optimal irrigation scheduling under restricted water availability conditions. Irrigation and Drainage, 66(4), 492-500. https://doi.org/10.1002/ird.2130.

13. Aria, M., \& Cuccurullo, C. (2016). bibliometrix: an $R$ tool for comprehensive bibliometric analysis of scientific literature. Naples: University of Naples Federico II.

14. Arsenault, R., Brissette, F., Malo, J.S., Minville, M., Leconte, R. (2013). Structural and non-structural climate change adaptation strategies for the Péribonka water resource system. Water Resources Management, 27(7), 2075-2087. https://doi.org/10. 1007/s11269-013-0275-6.

15. Asadabadi, A., \& Miller-Hook, E. (2017). Optimal transportation and shoreline infrastructure investment planning under a stochastic climate future. Transportation Research Part B-Methodological, 100, 156-174. https://doi.org/10.1016 /j.trb.2016.12.023.

16. BBC (2017). Mumbai flooding causes transport chaos, http:// www.bbc.co.uk/news/world-asia-41085606. Accessed 21 June 2018.

17. Behera, P.K., \& Teegavarapu, R.S.V. (2015). Optimization of a stormwater quality management pond system. Water Resources Management, 29(4), 1083-1095. https://doi.org/10.10 07/s11269-014-0862-1.

18. Bekri, E., Disse, M., Yannopoulos, P. (2015). Optimizing water allocation under uncertain system conditions for water and agriculture future scenarios in Alfeios River Basin (Greece)Part B: fuzzy-boundary intervals combined with multi-stage stochastic programming model. Water, 7(11), 6427-6466. https://doi.org/10.3390/w7116427.

19. Bekri, E., Disse, M., Yannopoulos, P. (2015). Optimizing water allocation under uncertain system conditions in Alfeios River Basin (Greece), part A: two-stage stochastic programming model with deterministic boundary intervals. Water, 7(10), 5305-5344. https://doi.org/10.3390/w7105305.

20. Belhouchette, H., Blanco, M., Wery, J., Flichman, G. (2012). Sustainability of irrigated farming systems in a Tunisian region: a recursive stochastic programming analysis. Computers and Electronics in Agriculture, 86(SI), 100-110. https://doi.org/10.1016/j.compag.2012.02.016.

21. Benoit, K. (2018). quanteda: quantitative analysis of textual data. http://quanteda.io, https://doi.org/10.5281/zenodo.1004683. R package version 1.3.0.

22. Bhaduri, A., \& Manna, U. (2014). Impacts of water supply uncertainty and storage on efficient irrigation technology adoption. Natural Resource Modeling, 27(1), 1-24. https://doi.org/10. 1111/nrm.12016.

23. Bolouri-Yazdeli, Y., Bozorg-Haddad, O., Fallah-Mehdipour, E., Marino, M.A. (2014). Evaluation of real-time operation rules in reservoir systems operation. Water Resources Management, 28(3), 715-729. https://doi.org/10.1007/s11269-013-0510-1.
24. Bourgeois, C., Ben Fradj, N., Jayet, P.A. (2014). How costeffective is a mixed policy targeting the management of three agricultural N-pollutants? Environmental Modeling \& Assessment, 19(5), 389-405. https://doi.org/10.1007/s1066 6-014-9401-y.

25. Bozorg-Haddad, O., Malmir, M., Mohammad-Azari, S., Loaiciga, H.A. (2016). Estimation of farmers' willingness to pay for water in the agricultural sector. Agricultural Water Management, 177, 284-290. https://doi.org/10.1016/j.agwat. 2016.08.011.

26. Bryan, B.A., Higgins, A., Overton, I.C., Holland, K., Lester, R.E., King, D., Nolan, M., MacDonald, D.H., Connor, J.D., Bjornsson, T., Kirby, M. (2013). Ecohydrological and socioeconomic integration for the operational management of environmental flows. Ecological Applications, 23(5), 999-1016. https://doi.org/10.1890/12-2104.1.

27. Cai, Y., Yue, W., Xu, L., Yang, Z., Rong, Q. (2016). Sustainable urban water resources management considering life-cycle environmental impacts of water utilization under uncertainty. Resources Conservation and Recycling, 108, 21-40. https://doi.org/10.1016/j.resconrec.2016.01.008.

28. Cai, Y.P., Huang, G.H., Tan, Q., Chen, B. (2011). Identification of optimal strategies for improving eco-resilience to floods in ecologically vulnerable regions of a wetland. Ecological Modelling, 222(2, SI), 360-369. https://doi.org/10.1016 /j.ecolmodel.2009.12.012.

29. Castelletti, A., Galelli, S., Restelli, M., Soncini-Sessa, R. (2010). Tree-based reinforcement learning for optimal water reservoir operation. Water Resources Research, 46. https://doi.org/10. 1029/2009WR008898.

30. Castelletti, A., Pianosi, F., Quach, X., Soncini-Sessa, R. (2012). Assessing water reservoirs management and development in northern Vietnam. Hydrology and Earth System Sciences, 16(1), 189-199. https://doi.org/10.5194/hess-16-189-2012.

31. Chandramouli, S., \& Nanduri, U.V. (2011). Comparison of stochastic and fuzzy dynamic programming models for the operation of a multipurpose reservoir. Water and Environment Journal, 25(4), 547-554. https://doi.org/10.1111/j.1747 $-6593.2011 .00255 . x$.

32. Chang, N.B., Chen, H.W., Ning, S.K., Hsu, H.Y., Shao, K.T., Hung, T.C. (2010). Sizing an off-stream reservoir with respect to water availability, water quality, and biological integrity. Environmental Modeling \& Assessment, 15(5), 329344. https://doi.org/10.1007/s10666-009-9215-5.

33. Chang, N.B., Yeh, S.C., Chang, C.H. (2011). Optimal expansion of a coastal wastewater treatment and ocean outfall system under uncertainty (II): optimisation analysis. Civil Engineering and Environmental Systems, 28(1), 39-59. https://doi.org/10.1080 /10286600903243138.

34. Chen, S., Shao, D., Gu, W., Xu, B., Li, H., Fang, L. (2017). An interval multistage water allocation model for crop different growth stages under inputs uncertainty. Agricultural Water Management, 186, 86-97. https://doi.org/10.1016/j.agwat 2017.03.001.

35. Chen, S., Shao, D., Tan, X., Gu, W., Lei, C. (2017). An interval multistage classified model for regional interand intra-seasonal water management under uncertain and nonstationary condition. Agricultural Water Management, 191, 98-112. https://doi.org/10.1016/j.agwat.2017.06.005.

36. Cote, P., Haguma, D., Leconte, R., Krau, S. (2011). Stochastic optimisation of Hydro-Quebec hydropower installations: a statistical comparison between SDP and SSDP methods. Canadian Journal of Civil Engineering, 38(12), 1427-1434. https://doi.org/10.1139/L11-101. 
37. Cote, P., \& Leconte, R. (2016). Comparison of stochastic optimization algorithms for hydropower reservoir operation with ensemble streamflow prediction. Journal of Water Resources Planning and Management, 142, 2. https://doi.org/10.1061/ (ASCE)WR.1943-5452.0000575.

38. Cui, L., Li, Y., Huang, G. (2015). Planning an agricultural water resources management system: a two-stage stochastic fractional programming model. Sustainability, 7(8), 9846-9863. https://doi.org/10.3390/su7089846.

39. Dai, C., Guo, H.C., Tan, Q., Ren, W. (2016). Development of a constructed wetland network for mitigating nonpoint source pollution through a GIS-based watershed-scale inexact optimization approach. Ecological Engineering, 96(SI), 94-108. https://doi.org/10.1016/j.ecoleng.2015.06.013.

40. Dai, Z.Y., \& Li, Y.P. (2013). A multistage irrigation water allocation model for agricultural land-use planning under uncertainty. Agricultural Water Management, 129, 69-79. https://doi.org/10.1016/j.agwat.2013.07.013.

41. Dariane, A.B., \& Moradi, A.M. (2016). Comparative analysis of evolving artificial neural network and reinforcement learning in stochastic optimization of multireservoir systems. Hydrological Sciences Journal-Journal des Sciences Hydrologiques, 61(6), 1141-1156. https://doi.org/10.1080/02626667.2014.986485.

42. Davidsen, C., Liu, S., Mo, X., Holm, P.E., Trapp, S., Rosbjerg, D., Bauer-Gottwein, P. (2015). Hydroeconomic optimization of reservoir management under downstream water quality constraints. Journal of Hydrology, 529(3), 1679-1689. https://doi.org/10.1016/j.jhydrol.2015.08.018.

43. Dong, C., Tan, Q., Huang, G.H., Cai, Y.P. (2014). A dual-inexact fuzzy stochastic model for water resources management and nonpoint source pollution mitigation under multiple uncertainties. Hydrology and Earth System Sciences, 18(5), 1793-1803. https://doi.org/10.5194/hess-18-1793-2014.

44. Dong, F., Liu, Y., Su, H., Liang, Z., Zou, R., Guo, H. (2016). Uncertainty-based multi-objective decision making with hierarchical reliability analysis under water resources and environmental constraints. Water Resources Management, 30(2), 805-822. https://doi.org/10.1007/s11269-015-1192-7.

45. Dono, G., Cortignani, R., Dell'Unto, D., Deligios, P., Doro, L., Lacetera, N., Mula, L., Pasqui, M., Quaresima, S., Vitali, A., Roggero, P.P. (2016). Winners and losers from climate change in agriculture: insights from a case study in the Mediterranean basin. Agricultural Systems, 147, 65-75. https://doi.org/10.1016/j.agsy.2016.05.013.

46. Dono, G., Cortignani, R., Doro, L., Giraldo, L., Ledda, L., Pasqui, M., Roggero, P.P. (2013). Adapting to uncertainty associated with short-term climate variability changes in irrigated Mediterranean farming systems. Agricultural Systems, 117, 1-12. https://doi.org/10.1016/j.agsy.2013.01.005.

47. Dono, G., Cortignani, R., Doro, L., Giraldo, L., Ledda, L., Pasqui, M., Roggero, P.P. (2013). An integrated assessment of the impacts of changing climate variability on agricultural productivity and profitability in an irrigated Mediterranean catchment. Water Resources Management, 27(10), 3607-3622. https://doi.org/10.1007/s11269-013-0367-3.

48. Dono, G., Cortignani, R., Giraldo, L., Pasqui, M., Roggero, P.P. (2014). Income impacts of climate change: irrigated farming in the Mediterranean and expected changes in probability of favorable and adverse weather conditions. German Journal of Agricultural Economics, 63(3), 177-186.

49. Dono, G., \& Mazzapicchio, G. (2010). Uncertain water supply in an irrigated Mediterranean area: an analysis of the possible economic impact of climate change on the farm sector.
Agricultural Systems, 103(6), 361-370. https://doi.org/10.1016 /j.agsy.2010.03.005.

50. Doole, G.J., \& Romera, A.J. (2014). Cost-effective regulation of nonpoint emissions from pastoral agriculture: a stochastic analysis. Australian Journal of Agricultural and Resource Economics, 58(3), 471-494. https://doi.org/10.1111/1467-8489.12034.

51. El Cham, D., Scardigno, A., Khadra, R. (2014). Equity for an integrated water resources management of irrigation systems in the Mediterranean: the case study of south Lebanon. New Medit, 13(4), 39-45.

52. Environment Protection Authority (EPA) Victoria (2012). Point and nonpoint sources of water pollution, http://www.epa.vic. gov.au/your-environment/water/protecting-victorias-waters/ point-and-nonpoint-sources-of-water-pollution. Accessed 21 June 2018.

53. Espada, R. Jr., Apan, A., McDougall, K. (2014). Spatial modelling of natural disaster risk reduction policies with Markov decision processes. Applied Geography, 53, 284-298. https://doi.org/10.1016/j.apgeog.2014.06.021.

54. Etkin, D., Kirshen, P., Watkins, D., Roncoli, C., Sanon, M., Some, L., Dembele, Y., Sanfo, J., Zoungrana, J., Hoogenboom, G. (2015). Stochastic programming for improved multiuse reservoir operation in Burkina Faso, West Africa. Journal of Water Resources Planning and Management, 141, 3. https://doi.org/10.1061/(ASCE)WR.1943-5452.0000396.

55. Eum, H.I., \& Kim, Y.O. (2010). The value of updating ensemble streamflow prediction in reservoir operations. Hydrological Processes, 24(20), 2888-2899. https://doi.org/10.1002/hyp.7702.

56. Eum, H.I., Kim, Y.O., Palmer, R.N. (2011). Optimal drought management using sampling stochastic dynamic programming with a hedging rule. Journal of Water Resources Planning and Management-ASCE, 137(1), 113-122. https://doi.org/10.1061 /(ASCE)WR.1943-5452.0000095.

57. Fallah-Mehdipour, E., Bozorg-Haddad, O., Marino, M.A. (2012). Real-time operation of reservoir system by genetic programming. Water Resources Management, 26(14), 4091-4103. https://doi.org/10.1007/s11269-012-0132-z.

58. Feng, M., Liu, P., Guo, S., Gui, Z., Zhang, X., Zhang, W., Xiong, L. (2017). Identifying changing patterns of reservoir operating rules under various inflow alteration scenarios. Advances in Water Resources, 104, 23-36. https://doi.org/10.1016/j.advwat res.2017.03.003.

59. Fernandez, M.A., Huang, P., McCarl, B., Mehta, V. (2016). Value of decadal climate variability information for agriculture in the Missouri River Basin. Climatic Change, 139(3-4), 517-533. https://doi.org/10.1007/s10584-016-1807-x.

60. Francois, B., Hingray, B., Creutin, J.D., Hendrickx, F. (2015). Estimating water system performance under climate change: influence of the management strategy modeling. Water Resources Management, 29(13), 4903-4918. https://doi.org/10.1007/s112 69-015-1097-5.

61. Galelli, S., Gandolfi, C., Soncini-Sessa, R., Agostani, D. (2010). Building a metamodel of an irrigation district distributedparameter model. Agricultural Water Management, 97(2), 187200. https://doi.org/10.1016/j.agwat.2009.09.007.

62. Galelli, S., \& Soncini-Sessa, R. (2010). Combining metamodelling and stochastic dynamic programming for the design of reservoir release policies. Environmental Modelling \& Software, 25(2), 209-222. https://doi.org/10.1016/j.envsoft.2009.08.001.

63. Gassman, P., Reyes, M., Green, C., Arnold, J. (2007). The soil and water assessment tool: historical development, applications, and future research directions. Transactions of the ASABE, 50(4), 1211. https://doi.org/10.13031/2013.23637. 
64. Gelati, E., Madsen, H., Rosbjerg, D. (2014). Reservoir operation using El Nino forecasts-case study of Daule Peripa and Baba, Ecuador. Hydrological Sciences Journal-Journal des Sciences Hydrologiques, 59(8), 1559-1581. https://doi.org/10.1080 /02626667.2013.831978.

65. Ghosh, S., \& Mujumdar, P.P. (2010). Fuzzy waste load allocation model: a multiobjective approach. Journal of Hydroinformatics, 12(1), 83-96. https://doi.org/10.2166/hydro.2010.028.

66. Giuliani, M., Li, Y., Cominola, A., Denaro, S., Mason, E., Castelletti, A. (2016). A Matlab toolbox for designing multi-objective optimal operations of water reservoir systems. Environmental Modelling \& Software, 85, 293-298. https://doi.org/10.1016/j.envsoft.2016.08.015.

67. Goor, Q., Halleux, C., Mohamed, Y., Tilmant, A. (2010). Optimal operation of a multipurpose multireservoir system in the Eastern Nile River Basin. Hydrology and Earth System Sciences, 14(10), 1895-1908. https://doi.org/10.5194/hess-14-1895-2010.

68. Goor, Q., Kelman, R., Tilmant, A. (2011). Optimal multipurposemultireservoir operation model with variable productivity of hydropower plants. Journal of Water Resources Planning and Management, 137(3), 258-267. https://doi.org/10.1061/ (ASCE)WR.1943-5452.0000117.

69. Grafton, R.Q., Chu, H.L., Stewardson, M., Kompas, T. (2011). Optimal dynamic water allocation: irrigation extractions and environmental tradeoffs in the Murray River, Australia. Water Resources Research, 47. https://doi.org/10.1029 /2010WR009786.

70. Gren, I.M. (2010). Climate change and the Water Framework directive: cost effectiveness and policy design for water management in the Swedish Malar Region. Climatic Change, 100(3-4), 463-484. https://doi.org/10.1007/s10584-009-9720-1.

71. Grosso, J.M., Ocampo-Martinez, C., Puig, V., Joseph, B. (2014). Chance-constrained model predictive control for drinking water networks. Journal of Process Control, 24(5), 504-516. https://doi.org/10.1016/j.jprocont.2014.01.010.

72. Gu, J.J., Guo, P., Huang, G.H. (2013). Inexact stochastic dynamic programming method and application to water resources management in Shandong China under uncertainty. Stochastic Environmental Research and Risk Assessment, 27(5), 12071219. https://doi.org/10.1007/s00477-012-0657-y.

73. Gu, J.J., Huang, G.H., Guo, P., Shen, N. (2013). Interval multistage joint-probabilistic integer programming approach for water resources allocation and management. Journal of Environmental Management, 128, 615-624. https://doi.org/10.1016 jj.jenvman.2013.06.013.

74. Guo, P., Huang, G.H., Li, Y.P. (2010). Inexact fuzzy-stochastic programming for water resources management under multiple uncertainties. Environmental Modeling \& Assessment, 15(2), 111-124. https://doi.org/10.1007/s10666-009-9194-6.

75. Guo, P., Wang, X., Zhu, H., Li, M. (2014). Inexact fuzzy chanceconstrained nonlinear programming approach for crop water allocation under precipitation variation and sustainable development. Journal of Water Resources Planning and Management, 140, 9. https://doi.org/10.1061/(ASCE)WR.1943-5452.0000385.

76. Gutjahr, W.J., \& Pichler, A. (2016). Stochastic multi-objective optimization: a survey on non-scalarizing methods. Annals of Operations Research, 236(2), 475-499. https://doi.org/10.1007 /s10479-013-1369-5.

77. Haguma, D., Leconte, R., Cote, P., Krau, S., Brissette, F. (2014). Optimal hydropower generation under climate change conditions for a northern water resources system. Water Resources Management, 28(13), 4631-4644. https://doi.org/10.1007/s1126 9-014-0763-3.

78. Haguma, D., Leconte, R., Krau, S., Cote, P., Brissette, F. (2015). Water resources optimization method in the context of climate change. Journal of Water Resources Planning and Management, 141, 2. https://doi.org/10.1061/(ASCE)WR.1943-5452.0000445.

79. Han, J.C., Huang, G.H., Zhang, H., Li, Z. (2013). Optimal land use management for soil erosion control by using an interval-parameter fuzzy two-stage stochastic programming approach. Environmental Management, 52(3), 621-638. https://doi.org/10.1007/s00267-013-0122-9.

80. Han, K., Noh, J., Kim, J.S., Lee, C. (2012). Application of stochastic optimization algorithm for waste load allocation in the Nakdong River Basin, Korea. KSCE Journal of Civil Engineering, 16(4), 650-659. https://doi.org/10.1007/s1 2205-012-0919-8.

81. Han, Y., Huang, Y., Jia, S., Liu, J. (2013). An intervalparameter fuzzy linear programming with stochastic vertices model for water resources management under uncertainty. Mathematical Problems in Engineering. https://doi.org/10.1155/2013/ 942343.

82. Han, Y., Huang, Y., Wang, G. (2011). Interval-parameter linear optimization model with stochastic vertices for land and water resources allocation under dual uncertainty. Environmental Engineering Science, 28(3), 197-205. https://doi.org/10.1089/ ees.2010.0160.

83. Heumesser, C., Fuss, S., Szolgayova, J., Strauss, F., Schmid, E. (2012). Investment in irrigation systems under precipitation uncertainty. Water Resources Management, 26(11), 3113-3137. https://doi.org/10.1007/s11269-012-0053-x.

84. Ho, C.C., Pan, C.C., Chang, L.C. (2017). Determining an optimal action portfolio for water resource management by using stochastic programming. Water Resources Management, 31(9), 2675-2687. https://doi.org/10.1007/s11269-017-1652-3.

85. Homayounfar, M., Zomorodian, M., Martinez, C.J., Lai, S.H. (2015). Two monthly continuous dynamic model based on Nash bargaining theory for conflict resolution in reservoir system. PLOS One, 10, 12. https://doi.org/10.1371/journal.pone. 0143198.

86. Hu, M., Huang, G.H., Sun, W., Li, Y.P. (2013). Inexact quadratic joint-probabilistic programming for water quality management under uncertainty in the Xiangxi River, China. Stochastic Environmental Research and Risk Assessment, 27(5), 11151132. https://doi.org/10.1007/s00477-012-0648-z.

87. Hu, X.H., Li, Y.P., Huang, G.H., Zhuang, X.W., Ding, X.W. (2016). A Bayesian-based two-stage inexact optimization method for supporting stream water quality management in the Three Gorges Reservoir region. Environmental Science and Pollution Research, 23(9), 9164-9182. https://doi.org/10.1007 /s11356-016-6106-6.

88. Huang, Y., Chen, X., Li, Y., Bao, A., Ma, Y. (2012). A simulation-based two-stage interval-stochastic programming model for water resources management in Kaidu-Konqi watershed, China. Journal of Arid Land, 4(4), 390-398. https://doi.org /10.3724/SP.J.1227.2012.00390.

89. Huang, Y., Li, Y.P., Chen, X., Bao, A.M., Ma, Y.G. (2013). A multistage simulation-based optimization model for water resources management in Tarim River Basin, China. Stochastic Environmental Research and Risk Assessment, 27(1), 147-158. https://doi.org/10.1007/s00477-012-0585-x.

90. Huang, Y., Li, Y.P., Chen, X., Ma, Y.G. (2012). Optimization of the irrigation water resources for agricultural sustainability in Tarim River Basin, China. Agricultural Water Management, 107, 74-85. https://doi.org/10.1016/j.agwat.2012.01.012.

91. Huang, Y.L., Huang, G.H., Liu, D.F., Zhu, H., Sun, W. (2012). Simulation-based inexact chance-constrained nonlinear programming for eutrophication management in the Xiangxi Bay of Three Gorges Reservoir. Journal of Environmental Management, 108, 54-65. https://doi.org/10.1016/j.jenvman.2012.04.037. 
92. Huh, W.T., \& Lall, U. (2013). Optimal crop choice, irrigation allocation, and the impact of contract farming. Production and Operations Management, 22(5), 1126-1143. https://doi.org/10. 1111/poms.12007.

93. Hyytiainen, K., Lehtiniemi, M., Niemi, J.K., Tikka, K. (2013). An optimization framework for addressing aquatic invasive species. Ecological Economics, 91, 69-79. https://doi.org/10. 1016/j.ecolecon.2013.04.001.

94. Jaafar, H.H., Al-Awar, F., Ahmad, F. (2016). Effect of inflow class selection on multi-objective reservoir operation using stochastic dynamic programming. Arabian Journal for Science and Engineering, 41(12), 4911-4926. https://doi.org/10.1007 /s13369-016-2185-4.

95. Jafarzadegan, K., Abed-Elmdoust, A., Kerachian, R. (2013). A fuzzy variable least core game for inter-basin water resources allocation under uncertainty. Water Resources Management, 27(9), 3247-3260. https://doi.org/10.1007/s11269-013-0344-x.

96. Jansouz, P., Shahraki, J., Abdolhosseini, M. (2017). Is water trading policy an effective solution for water allocation in Voshmgir dam? Water Policy, 19(6), 1119-1142. https://doi.org/10. 2166/wp.2017.121.

97. Jayet, P.A., \& Petsakos, A. (2013). Evaluating the efficiency of a uniform $\mathrm{N}$-input tax under different policy scenarios at different scales. Environmental Modeling \& Assessment, 18(1), 57-72. https://doi.org/10.1007/s10666-012-9331-5.

98. Jing, L., Chen, B., Zhang, B., Li, P. (2013). A hybrid stochasticinterval analytic hierarchy process approach for prioritizing the strategies of reusing treated wastewater. Mathematical Problems in Engineering. https://doi.org/10.1155/2013/874805.

99. Jing, L., Chen, B., Zhang, B., Peng, H. (2012). A review of ballast water management practices and challenges in harsh and arctic environments. Environmental Reviews, 20(2), 83-108. https://doi.org/10.1139/A2012-002.

100. Kahil, M.T., Connor, J.D., Albiac, J. (2015). Efficient water management policies for irrigation adaptation to climate change in Southern Europe. Ecological Economics, 120, 226-233. https://doi.org/10.1016/j.ecolecon.2015.11.004.

101. Kana, A.A. (2017). Forecasting design and decision paths in ship design using the ship-centric Markov decision process model. Ocean Engineering, 137, 328-337. https://doi.org/10.10 16/j.oceaneng.2017.04.012.

102. Kataria, M., Elofsson, K., Hasler, B. (2010). Distributional assumptions in chance-constrained programming models of stochastic water pollution. Environmental Modeling \& Assessment, 15(4), 273-281. https://doi.org/10.1007/s10666-009-920 5-7.

103. Koker, E., \& Altan-Sakarya, A.B. (2015). Chance constrained optimization of booster chlorination in water distribution networks. Clean-Soil Air Water, 43(5), 717-723. https://doi.org/10. 1002/clen.201400119.

104. Kumari, S., \& Mujumdar, P.P. (2015). Reservoir operation with fuzzy state variables for irrigation of multiple crops. Journal of Irrigation and Drainage Engineering, 141, 11. https://doi. org/10.1061/(ASCE)IR.1943-4774.0000893.

105. Kumari, S., \& Mujumdar, P.P. (2017). Fuzzy set-based system performance evaluation of an irrigation reservoir system. Journal of Irrigation and Drainage Engineering, 143, 5. https://doi.org/ 10.1061/(ASCE)IR.1943-4774.0001155.

106. Li, L.J., Zhou, R.J., Dong, H.G. (2010). State-time-space superstructure-based MINLP formulation for batch waterallocation network design. Industrial \& Engineering Chemistry Research, 49(1), 236-251. https://doi.org/10.1021/ie900427b.

107. Li, M., \& Guo, P. (2015). A coupled random fuzzy two-stage programming model for crop area optimization - a case study of the middle Heihe River Basin, China. Agricultural Water Management, 155, 53-66. https://doi.org/10.1016/j.agwat.2015.03.013.

108. Li, M., Guo, P., Ren, C. (2015). Water resources management models based on two-level linear fractional programming method under uncertainty. Journal of Water Resources Planning and Management, 141, 9. https://doi.org/10.1061/ (ASCE)WR.1943-5452.0000518.

109. Li, M., Guo, P., Singh, V.P., Zhao, J. (2016). Irrigation water allocation using an inexact two-stage quadratic programming with fuzzy input under climate change. Journal of the American Water Resources Association, 52(3), 667-684. https://doi.org/10.1111/1752-1688.12415.

110. Li, M., Guo, P., Yang, G.Q., Fang, S.Q. (2014). IB-ICCMSP: an integrated irrigation water optimal allocation and planning model based on inventory theory under uncertainty. Water Resources Management, 28(1), 241-260. https://doi.org/10.10 07/s11269-013-0482-1.

111. Li, M., Guo, P., Zhang, L., Zhao, J. (2015). Multi-dimensional critical regulation control modes and water optimal allocation for irrigation system in the middle reaches of Heihe River Basin, China. Ecological Engineering, 76, 166-177. https://doi.org/10.1016/j.ecoleng.2014.03.036.

112. Li, N., Yang, H., Wang, L., Huang, X., Zeng, C., Wu, H., Ma, X., Song, X., Wei, Y. (2016). Optimization of industry structure based on water environmental carrying capacity under uncertainty of the Huai River Basin within Shandong Province, China. Journal of Cleaner Production, 112(5), 4594-4604. https://doi.org/10.1016/j.jclepro.2015.08.074.

113. Li, T., Li, P., Chen, B., Hu, M., Zhang, X. (2014). Simulationbased inexact two- stage chance- constraint quadratic programming for sustainable water quality management under dual uncertainties. Journal of Water Resources Planning and Management, 140(3), 298-312. https://doi.org/10.1061/(ASCE)WR. 1943-5452.0000328.

114. Li, W., Feng, C., Dai, C., Li, Y., Li, C., Liu, M. (2016). An inexact risk management model for agricultural land-use planning under water shortage. Frontiers of Earth Science, 10(3), 419-431. https://doi.org/10.1007/s11707-015-0544-1.

115. Li, W., Li, Y.P., Li, C.H., Huang, G.H. (2010). An inexact twostage water management model for planning agricultural irrigation under uncertainty. Agricultural Water Management, 97(11), 1905-1914. https://doi.org/10.1016/j.agwat.2010.07.005.

116. Li, X., Huo, Z., Xu, B. (2017). Optimal allocation method of irrigation water from river and lake by considering the field water cycle process. Water, 9, 12. https://doi.org/10.3390/w9120911.

117. Li, X., Lu, H., He, L., Shi, B. (2014). An inexact stochastic optimization model for agricultural irrigation management with a case study in China. Stochastic Environmental Research and Risk Assessment, 28(2), 281-295. https://doi.org/10.1007/s00477-01 3-0748-4.

118. Li, Y., Li, W., Huang, G. (2012). Two-stage inexactprobabilistic programming model for water quality management. Environmental Engineering Science, 29(7), 713-725. https://doi.org/10.1089/ees.2011.0317.

119. Li, Y.P., \& Huang, G.H. (2010). Inexact joint-probabilistic stochastic programming for water resources management under uncertainty. Engineering Optimization, 42(11), 1023-1037. https://doi.org/10.1080/03052151003622539.

120. Li, Y.P., \& Huang, G.H. (2011). Planning agricultural water resources system associated with fuzzy and random features. Journal of the American Water Resources Association, 47(4), 841-860. https://doi.org/10.1111/j.1752-1688.2011.00558.x.

121. Li, Y.P., \& Huang, G.H. (2012). A recourse-based nonlinear programming model for stream water quality management. 
Stochastic Environmental Research and Risk Assessment, 26(2), 207-223. https://doi.org/10.1007/s00477-011-0468-6.

122. Li, Y.P., Huang, G.H., Li, H.Z., Liu, J. (2014). A recourse-based interval fuzzy programming model for point-nonpoint source effluent trading under uncertainty. Journal of the American Water Resources Association, 50(5), 1191-1207. https://doi.org/10.11 11/jawr.12183.

123. Li, Y.P., Huang, G.H., Nie, S.L. (2010). Planning water resources management systems using a fuzzy-boundary interval-stochastic programming method. Advances in Water Resources, 33(9), 1105-1117. https://doi.org/10.1016/j.advwatres.2010.06.015.

124. Li, Y.P., Liu, J., Huang, G.H. (2014). A hybrid fuzzy-stochastic programming method for water trading within an agricultural system. Agricultural Systems, 123, 71-83. https://doi.org/10. 1016/j.agsy.2013.10.001.

125. Li, Y.P., Nie, S., Huang, C.Z., McBean, E.A., Fan, Y.R., Huang, G.H. (2017). An integrated risk analysis method for planning water resource systems to support sustainable development of an arid region. Journal of Environmental Informatics, 29(1), 1-15. https://doi.org/10.3808/jei.201700359.

126. Li, Z., Huang, G., Zhang, Y., Li, Y. (2013). Inexact two-stage stochastic credibility constrained programming for water quality management. Resources Conservation and Recycling, 73, 122132. https://doi.org/10.1016/j.resconrec.2013.01.008.

127. Liao, S.Y., Chen, C.C., Hsu, S.H. (2010). Estimating the value of El Nino southern oscillation information in a regional water market with implications for water management. Journal of Hydrology, 394(3-4), 347-356. https://doi.org/10.10 16/j.jhydrol.2010.09.008.

128. Liu, J., Li, Y., Huang, G., Chen, L. (2017). A recourse-based type-2 fuzzy programming method for water pollution control under uncertainty. Symmetry-Basel, 9, 11. https://doi.org/10.33 90/sym9110265.

129. Liu, J., Li, Y., Huang, G., Fu, H., Zhang, J., Cheng, G. (2017). Identification of water quality management policy of watershed system with multiple uncertain interactions using a multi-level-factorial risk-inference-based possibilistic-probabilistic programming approach. Environmental Science and Pollution Research, 24(17), 14980-15000. https://doi.org/10.1007/s11356-017-9106-2.

130. Liu, J., Li, Y., Huang, G., Suo, C., Yin, S. (2017). An interval fuzzy-stochastic chance-constrained programming based energy-water nexus model for planning electric power systems. Energies, 10, 11. https://doi.org/10.3390/en10111914.

131. Liu, J., Li, Y.P., Huang, G.H., Zeng, X.T. (2014). A dualinterval fixed-mix stochastic programming method for water resources management under uncertainty. Resources Conservation and Recycling, 88, 50-66. https://doi.org/10.1016/j.res conrec.2014.04.010.

132. Liu, J., Li, Y.P., Huang, G.H., Zeng, X.T., Nie, S. (2016). An integrated optimization method for river water quality management and risk analysis in a rural system. Environmental Science and Pollution Research, 23(1), 477-497. https://doi.org/10.1007 /s11356-015-5250-8.

133. Liu, J., Li, Y.P., Huang, G.H., Zhuang, X.W., Fu, H.Y. (2017). Assessment of uncertainty effects on crop planning and irrigation water supply using a Monte Carlo simulation based dual-interval stochastic programming method. Journal of Cleaner Production, 149, 945-967. https://doi.org/10.1016/j.jclepro.2017.02. 100.

134. Liu, M., Huang, G.H., Liao, R.F., Li, Y.P., Xie, Y.L. (2013). Fuzzy two-stage non-point source pollution management model for agricultural systems-a case study for the Lake Tai Basin, China. Agricultural Water Management, 121, 27-41. https://doi.org/10.1016/j.agwat.2013.01.006.
135. Liu, X.M., Huang, G.H., Wang, S., Fan, Y.R. (2016). Water resources management under uncertainty: factorial multi-stage stochastic program with chance constraints. Stochastic Environmental Research and Risk Assessment, 30(3), 945-957. https://doi.org/10.1007/s00477-015-1143-0.

136. Lu, H., Huang, G., He, L. (2011). An inexact roughinterval fuzzy linear programming method for generating conjunctive water-allocation strategies to agricultural irrigation systems. Applied Mathematical Modelling, 35(9), 4330-4340. https://doi.org/10.1016/j.apm.2011.03.008.

137. Lv, Y., Huang, G.H., Li, Y.P., Sun, W. (2012). Managing water resources system in a mixed inexact environment using superiority and inferiority measures. Stochastic Environmental Research and Risk Assessment, 26(5), 681-693. https://doi.org/10.1007 /s00477-011-0533-1.

138. Mabaya, G., Unami, K., Fujihara, M. (2017). Stochastic optimal control of agrochemical pollutant loads in reservoirs for irrigation. Journal of Cleaner Production, 146(SI), 37-46. https://doi. org/10.1016/j.jclepro.2016.05.108.

139. Maeda, S., Kawachi, T., Unami, K., Takeuchi, J., Ichion, E. (2010). Controlling wasteloads from point and nonpoint sources to river system by GIS-aided epsilon robust optimization model. Journal of Hydro-Environment Research, 4(1), 27-36. https://doi.org/10.1016/j.jher.2009.04.002.

140. Marinoni, O., Heyenga, S., Brigden, A., Archer, A., Higgins, A. (2012). Spending environmental expenditure more effectively: a case study from Brisbane, Australia. Environmental Modeling \& Assessment, 17(3), 315-324. https://doi.org/10.1007 /s10666-011-9285-z.

141. Meng, C., Wang, X., Li, Y. (2017). An optimization model for waste load allocation under water carrying capacity improvement management, a case study of the Yitong River, Northeast China. Water, 9, 8. https://doi.org/10.3390/w9080573.

142. Moeini, R., Afshar, A., Afshar, M.H. (2011). Fuzzy rulebased model for hydropower reservoirs operation. International Journal of Electrical Power \& Energy Systems, 33(2), 171-178. https://doi.org/10.1016/j.ijepes.2010.08.012.

143. Moosavian, S.A.A., Ghaffari, A., Salimi, A. (2010). Sequential quadratic programming and analytic hierarchy process for nonlinear multiobjective optimization of a hydropower network. Optimal Control Applications \& Methods, 31(4), 351-364. https://doi.org/10.1002/oca.909.

144. Muhammad, Y.S., \& Pflug, G.C. (2014). Stochastic vs deterministic programming in water management: the value of flexibility. Annals of Operations Research, 223(1), 309-328. https://doi.org/10.1007/s10479-013-1455-8.

145. Nematian, J. (2016). An extended two-stage stochastic programming approach for water resources management under uncertainty. Journal of Environmental Informatics, 27(2), 72-84. https://doi.org/10.3808/jei.201600334.

146. New York Times (2017). Stalled over gulf, Harvey deepens Texan's soggy misery, https://www.nytimes.com/2017/08/29/us/ harvey-texas-louisiana.html. Accessed 21 June 2018.

147. New York Times (2017). 'This is too much for us': Sierra Leone deluged by mud and grief. https://www.nytimes.com/2017/08/ 15/world/africa/sierra-leone-freetown-mudslides-floods.html. Accessed 21 June 2018.

148. New Zealand Herald (2017). Labour leader Jacinda Ardern wants royalty on commercial freshwater use to help clean up rivers https://www.nzherald.co.nz/nz/news/article.cfm?c_id=1\& objectid=11900746. Accessed 21 June 2018 .

149. Niese, N.D., \& Singer, D.J. (2013). Strategic life cycle decisionmaking for the management of complex systems subject to uncertain environmental policy. Ocean Engineering, 72, 365374. https://doi.org/10.1016/j.oceaneng.2013.07.020. 
150. Nikoo, M.R., Karimi, A., Kerachian, R. (2013). Optimal longterm operation of reservoir-river systems under hydrologic uncertainties: application of interval programming. Water Resources Management, 27(11), 3865-3883. https://doi.org/10.1007/s1126 9-013-0384-2.

151. Nikoo, M.R., Kerachian, R., Karimi, A., Azadnia, A.A., Jafarzadegan, K. (2014). Optimal water and waste load allocation in reservoir-river systems: a case study. Environmental Earth Sciences, 71(9), 4127-4142. https://doi.org/10.1007 /s12665-013-2801-5.

152. Niu, G., Li, Y.P., Huang, G.H., Liu, J., Fan, Y.R. (2016). Crop planning and water resource allocation for sustainable development of an irrigation region in China under multiple uncertainties. Agricultural Water Management, 166, 53-69. https://doi.org/10.1016/j.agwat.2015.12.011.

153. Ozmen, A., Batmaz, I., Weber, G.W. (2014). Precipitation modeling by polyhedral RCMARS and comparison with MARS and CMARS. Environmental Modeling \& Assessment, 19(5), 425-435. https://doi.org/10.1007/s10666-014-9404-8.

154. Parra-Guevara, D., \& Skiba, Y.N. (2013). A linear-programmingbased strategy for bioremediation of oil-polluted marine environments. Environmental Modeling \& Assessment, 18(2), 135-146. https://doi.org/10.1007/s10666-012-9337-z.

155. Pena-Haro, S., Pulido-Velazquez, M., Llopis-Albert, C. (2011). Stochastic hydro-economic modeling for optimal management of agricultural groundwater nitrate pollution under hydraulic conductivity uncertainty. Environmental Modelling \& Software, 26(8), 999-1008. https://doi.org/10.1016/j.envsoft.2011.02. 010.

156. Pereira-Cardenal, S.J., Madsen, H., Arnbjerg-Nielsen, K., Riegels, N., Jensen, R., Mo, B., Wangensteen, I., BauerGottwein, P. (2014). Assessing climate change impacts on the Iberian power system using a coupled water-power model. Climatic Change, 126(3-4), 351-364. https://doi.org/10. 1007/s10584-014-1221-1.

157. Pereira-Cardenal, S.J., Mo, B., Gjelsvik, A., Riegels, N.D., Arnbjerg-Nielsen, K., Bauer-Gottwein, P. (2016). Joint optimization of regional water-power systems. Advances in Water Resources, 92, 200-207. https://doi.org/10.1016/j.advwatres. 2016.04.004.

158. Pereira-Cardenal, S.J., Mo, B., Riegels, N.D., Arnbjerg-Nielsen, K., Bauer-Gottwein, P. (2015). Optimization of multipurpose reservoir systems using power market models. Journal of Water Resources Planning and Management, 141, 8. https://doi.org/10.1061/(ASCE)WR.1943-5452.0000500.

159. Pflug, G.C., \& Pichler, A. (2014). Multistage stochastic optimization. Springer series in operations research and financial engineering. Switzerland: Springer.

160. Pianosi, F., Castelletti, A., Restelli, M. (2013). Tree-based fitted Q-iteration for multi-objective Markov decision processes in water resource management. Journal of Hydroinformatics, 15(2), 258-270. https://doi.org/10.2166/hydro.2013.169.

161. Pina, J., Tilmant, A., Anctil, F. (2017). Horizontal approach to assess the impact of climate change on water resources systems. Journal of Water Resources Planning and Management, 143, 4. https://doi.org/10.1061/(ASCE)WR.1943-5452.0000737.

162. van der Pol, T.D., van Ierland, E.C., Weikard, H.P. (2014). Optimal dike investments under uncertainty and learning about increasing water levels. Journal of Flood Risk Management, 7(4), 308-318. https://doi.org/10.1111/jfr3.12063.

163. Poorsepahy-Samian, H., Espanmanesh, V., Zahraie, B. (2016). Improved inflow modeling in stochastic dual dynamic programming. Journal of Water Resources Planning and Management, 142, 12. https://doi.org/10.1061/(ASCE)WR.19435452.0000713 .
164. Powell, W.B. (2007). Approximate dynamic programming: solving the curses of dimensionality. Wiley series in probability and statistics. New York: Wiley.

165. de Queiroz, A.R. (2016). Stochastic hydro-thermal scheduling optimization: an overview. Renewable \& Sustainable Energy Reviews, 62, 382-395. https://doi.org/10.1016/j.rser.2016.04. 065 .

166. de Queiroz, A.R., Marangon Lima, L.M., Marangon Lima, J.W., da Silva, B.C., Scianni, L.A. (2016). Climate change impacts in the energy supply of the Brazilian hydro-dominant power system. Renewable Energy, 99, 379-389. https://doi.org/10.10 16/j.renene.2016.07.022.

167. Raje, D., \& Mujumdar, P.P. (2010). Reservoir performance under uncertainty in hydrologic impacts of climate change. Advances in Water Resources, 33(3), 312-326. https://doi.org/10.1016/ j.advwatres.2009.12.008

168. Rani, D., \& Moreira, M.M. (2010). Simulation-optimization modeling: a survey and potential application in reservoir systems operation. Water Resources Management, 24(6), 1107-1138. https://doi.org/10.1007/s11269-009-9488-0.

169. Ray, P.A., Kirshen, P.H., Watkins, D. W. Jr. (2012). Staged climate change adaptation planning for water supply in Amman, Jordan. Journal of Water Resources Planning and ManagementASCE, 138(5), 403-411. https://doi.org/10.1061/(ASCE)WR.19 43-5452.0000172.

170. Rehana, S., \& Mujumdar, P.P. (2014). Basin scale water resources systems modeling under cascading uncertainties. Water Resources Management, 28(10), 3127-3142. https://doi.org/10. 1007/s11269-014-0659-2.

171. Ren, C.F., Guo, P., Li, M., Gu, J.J. (2013). Optimization of industrial structure considering the uncertainty of water resources. Water Resources Management, 27(11), 3885-3898. https://doi.org/10.1007/s11269-013-0385-1.

172. Ren, C.F., Li, R.H., Zhang, L.D., Guo, P. (2016). Multiobjective stochastic fractional goal programming model for water resources optimal allocation among industries. Journal of Water Resources Planning and Management, 142, 10. https://doi.org/10.1061/(ASCE)WR.1943-5452.0000681.

173. Rey, D., Calatrava, J., Garrido, A. (2016). Optimisation of water procurement decisions in an irrigation district: the role of option contracts. Australian Journal of Agricultural and Resource Economics, 60(1), 130-154. https://doi.org/10.1111 /1467-8489.12110.

174. Rieker, J.D., \& Labadie, J.W. (2012). An intelligent agent for optimal river-reservoir system management. Water Resources Research, 48. https://doi.org/10.1029/2012WR011958.

175. Rong, Q., Cai, Y., Chen, B., Yue, W., Yin, X., Tan, Q. (2017). An enhanced export coefficient based optimization model for supporting agricultural nonpoint source pollution mitigation under uncertainty. Science of the Total Environment, 580, 13511362. https://doi.org/10.1016/j.scitotenv.2016.12.099.

176. Rosenberg, D.E. (2015). Blended near-optimal alternative generation, visualization, and interaction for water resources decision making. Water Resources Research, 51(4), 2047-2063. https://doi.org/10.1002/2013WR014667.

177. Rouge, C., \& Tilmant, A. (2016). Using stochastic dual dynamic programming in problems with multiple near-optimal solutions. Water Resources Research, 52(5), 4151-4163. https://doi.org /10.1002/2016WR018608.

178. Schwartz, S.S. (2010). Optimization and decision heuristics for Chesapeake Bay nutrient reduction strategies. Environmental Modeling \& Assessment, 15(5), 345-359. https://doi.org/10.10 07/s10666-009-9211-9.

179. Shiklomanov, I.A. (1993). World fresh water resources. In Gleick, P. (Ed.) Water in crisis: a guide to the world's fresh water 
resources (pp. 13-24). New York: Oxford University Press. Chapter 2.

180. Shokri, A., Bozorg-Haddad, O., Marino, M.A. (2013). Reservoir operation for simultaneously meeting water demand and sediment flushing: stochastic dynamic programming approach with two uncertainties. Journal of Water Resources Planning and Management, 139(3), 277-289. https://doi.org/10.10 61/(ASCE)WR.1943-5452.0000244.

181. Singh, A. (2012). An overview of the optimization modelling applications. Journal of Hydrology, 466, 167-182. https://doi. org/10.1016/j.jhydrol.2012.08.004.

182. Soleimani, S., Bozorg-Haddad, O., Loaiciga, H.A. (2016). Reservoir operation rules with uncertainties in reservoir inflow and agricultural demand derived with stochastic dynamic programming. Journal of Irrigation and Drainage Engineering, 142, 11. https://doi.org/10.1061/(ASCE)IR.1943-4774.0001065.

183. Sreekanth, J., \& Datta, B. (2014). Stochastic and robust multiobjective optimal management of pumping from coastal aquifers under parameter uncertainty. Water Resources Management, 28(7), 2005-2019. https://doi.org/10.1007/s11269-014-0591-5.

184. Steeger, G., Barroso, L.A., Rebennack, S. (2014). Optimal bidding strategies for hydro-electric producers: a literature survey. IEEE Transactions on Power Systems, 29(4), 1758-1766. https://doi.org/10.1109/TPWRS.2013.2296400.

185. Tang, G., Zhou, H., Li, N. (2010). Reservoir optimization model incorporating inflow forecasts with various lead times as hydrologic state variables. Journal of Hydroinformatics, 12(3), 292-302. https://doi.org/10.2166/hydro.2009.088.

186. Tang, G., Zhou, H., Li, N., Wang, F., Wang, Y., Jian, D. (2010). Value of medium-range precipitation forecasts in inflow prediction and hydropower optimization. Water Resources Management, 24(11), 2721-2742. https://doi.org/10.1007/s1126 9-010-9576-1.

187. Tavakoli, A., Nikoo, M.R., Kerachian, R., Soltani, M. (2015). River water quality management considering agricultural return flows: application of a nonlinear two-stage stochastic fuzzy programming. Environmental Monitoring and Assessment, 187, 4. https://doi.org/10.1007/s10661-015-4263-6.

188. Tilmant, A., Beevers, L., Muyunda, B. (2010). Restoring a flow regime through the coordinated operation of a multireservoir system: the case of the Zambezi River Basin. Water Resources Research, 46. https://doi.org/10.1029/2009WR008897.

189. Torres, M.d.O., Howitt, R., Rodrigues, L.N. (2016). Modeling the economic benefits and distributional impacts of supplemental irrigation. Water Resources and Economics, 14, 1-12. https://doi.org/10.1016/j.wre.2016.03.001.

190. United Nations (2006). UN millennium project: goals, targets and indicators, https://millenniumindicators.un.org/unsd/mdg/. Accessed 21 June 2018.

191. UNited Nations (2014). Water quality, https://www.un.org/ waterforlifedecade/quality.shtml. Accessed 21 June 2018.

192. United Nations (2015). The united nations world water development report 2015: water for a sustainable world technical report, UNESCO, Paris.

193. United Nations (2016). The United Nations world water development report 2016: water and jobs technical report, UNESCO, Paris.

194. United Nations (2016). UN agencies to meet on El Niño's 'devastating impact' in Central America's Dry Corridor, http://www. un.org/apps/news/story.asp?NewsID=54342\#.WaQA9mdCh1E. Accessed 21 June 2018.

195. United Nations (2017). The united nations world water development report 2017. Wastewater: the untapped resource technical report, UNESCO, Paris.
196. United Nations (2017). Water scarcity, http://www.unwater.org/ water-facts/scarcity/. Accessed 21 June 2018.

197. Verdaguer, M., Suy, J., Villaret, M., Clara, N., Bofill, M., Poch, M. (2016). An exact approach for the prioritization process of industrial influents in wastewater systems. Clean Technologies and Environmental Policy, 18(1), 339-346. https://doi.org/10. 1007/s10098-015-0992-z.

198. Verderame, P.M., Elia, J.A., Li, J., Floudas, C.A. (2010). Planning and scheduling under uncertainty: a review across multiple sectors. Industrial \& Engineering Chemistry Research, 49(9), 3993-4017. https://doi.org/10.1021/ie902009k

199. Wang, B., Cai, Y., Yin, X., Tan, Q., Hao, Y. (2017). An integrated approach of system dynamics, orthogonal experimental design and inexact optimization for supporting water resources management under uncertainty. Water Resources Management, 31(5), 1665-1694. https://doi.org/10.1007/s11269-017-1608-7.

200. Wang, B., Li, W., Huang, G.H., Liu, L., Ji, L., Li, Y. (2015). Urban water resources allocation under the uncertainties of water supply and demand: a case study of Urumqi, China. Environmental Earth Sciences, 74(4), 3543-3557. https://doi.org/10.10 07/s12665-015-4420-9.

201. Wang, S., \& Huang, G.H. (2012). Identifying optimal water resources allocation strategies through an interactive multistage stochastic fuzzy programming approach. Water Resources Management, 26(7), 2015-2038. https://doi.org/10.1007/s11269 -012-9996-1.

202. Wang, S., \& Huang, G.H. (2015). A multi-level Taguchi-factorial two-stage stochastic programming approach for characterization of parameter uncertainties and their interactions: an application to water resources management. European Journal of Operational Research, 240(2), 572-581. https://doi.org/10.10 16/j.ejor.2014.07.011.

203. Wang, Y.Y., Huang, G.H., Wang, S., Li, W., Guan, P.B. (2016). A risk-based interactive multi-stage stochastic programming approach for water resources planning under dual uncertainties. Advances in Water Resources, 94, 217-230. https://doi.org/10.10 16/j.advwatres.2016.05.011.

204. WHO/UNICEF Joint Monitoring Programme for Water Supply and Sanitation (2015). Progress on sanitation and drinking water - 2015 update and MDG assessment. Technical Report World Health Organization (WHO) and the United Nations Children's Fund, UNICEF, Geneva.

205. WHO/UNICEF Joint Monitoring Programme for Water Supply and Sanitation (2017). Progress on drinking water, sanitation and hygiene: 2017 update and SDG baselines. Technical Report World Health Organization (WHO) and the United Nations Children's Fund, UNICEF, Geneva.

206. Wu, E.M.Y., Kuo, S.L., Kuo, C.L. (2011). Optimal design of water treatment facilities under nonlinear conditions with uncertainty based on flexible tolerance concept. Environmental Engineering Science, 28(4), 275-282. https://doi.org/10.1089/ ees.2010.0167.

207. Xie, Y., Huang, G., Li, W., Li, Y., Cui, J., Sun, X. (2016). A risk-based balance inexact optimization model for water quality management with sustainable wetland system developmenta case study of north China. Wetlands, 36(1), S205-S222. https://doi.org/10.1007/s13157-014-0604-4.

208. Xie, Y.L., \& Huang, G.H. (2014). Development of an inexact two-stage stochastic model with downside risk control for water quality management and decision analysis under uncertainty. Stochastic Environmental Research and Risk Assessment, 28(6), 1555-1575. https://doi.org/10.1007/s00477-013-0834-7.

209. Xie, Y.L., Huang, G.H., Li, W., Li, J.B., Li, Y.F. (2013). An inexact two-stage stochastic programming model for water resources 
management in Nansihu Lake Basin, China. Journal of Environmental Management, 127, 188-205. https://doi.org/10.1016 jj.jenvman.2013.04.027.

210. Xin, X., Huang, G., Sun, W., Zhou, Y., Fan, Y. (2016). Factorial two-stage irrigation system optimization model. Journal of Irrigation and Drainage Engineering, 142, 2. https://doi.org/10. 1061/(ASCE)IR.1943-4774.0000951.

211. Xu, B., Zhong, P.a., Wu, Y., Fu, F., Chen, Y., Zhao, Y. (2017). A multiobjective stochastic programming model for hydropower hedging operations under inexact information. Water Resources Management, 31(14), 4649-4667. https://doi.org/10.1007/s112 69-017-1771-x.

212. Xu, J., Huang, G., Li, Z., Chen, J. (2017). A two-stage fuzzy chance-constrained water management model. Environmental Science and Pollution Research, 24(13), 12437-12454. https://doi.org/10.1007/s11356-017-8725-y.

213. Xu, J., Li, Y., Huang, G. (2013). A hybrid interval-robust optimization model for water quality management. Environmental Engineering Science, 30(5), 248-263. https://doi.org/10.10 89/ees.2012.0083.

214. Xu, J., Tu, Y., Zeng, Z. (2013). Bilevel optimization of regional water resources allocation problem under fuzzy random environment. Journal of Water Resources Planning and Management-ASCE, 139(3), 246-264. https://doi.org/10.10 61/(ASCE)WR.1943-5452.0000248.

215. Xu, W., Peng, Y., Wang, B. (2013). Evaluation of optimization operation models for cascaded hydropower reservoirs to utilize medium range forecasting inflow. Science ChinaTechnological Sciences, 56(10), 2540-2552. https://doi.org/10. 1007/s11431-013-5346-7.

216. Xu, W., Zhang, C., Peng, Y., Fu, G., Zhou, H. (2014). A two stage Bayesian stochastic optimization model for cascaded hydropower systems considering varying uncertainty of flow forecasts. Water Resources Research, 50(12), 9267-9286. https://doi.org/10.1002/2013WR015181.

217. Xu, Y., \& Huang, G. (2016). A risk-based interval twostage programming model for agricultural system management under uncertainty. Mathematical Problems in Engineering. https://doi.org/10.1155/2016/7438913.

218. Yakowitz, S. (1982). Dynamic-programming applications in water-resources. Water Resources Research, 18(4), 673-696. https://doi.org/10.1029/WR018i004p00673.

219. Yang, L., Grossmann, I.E., Manno, J. (2014). Optimization models for shale gas water management. AIChE Journal, 60(10), 3490-3501. https://doi.org/10.1002/aic.14526.

220. Yuan, L., Zhou, J., Li, C., Xie, M., Mo, L. (2016). Benefit and risk balance optimization for stochastic hydropower scheduling. Water Resources Management, 30(10), 3347-3361. https://doi.org/10.1007/s11269-016-1354-2.

221. Zagonari, F. (2016). A non-probabilistic methodology for reliable sustainability planning: an application to the Iraqi national irrigation system. Applied Mathematical Modelling, 40(23-24), 10563-10577. https://doi.org/10.1016/j.apm.2016.07.029.

222. Zeng, X., Li, Y., Huang, G., Yu, L. (2014). Inexact mathematical modeling for the identification of water trading policy under uncertainty. Water, 6(2), 229-252. https://doi.org/10. 3390/w6020229.

223. Zeng, X., Yang, X., Yu, L., Chen, H. (2015). A mix inexact-quadratic fuzzy water resources management model of floodplain (IQT-WMMF) for regional sustainable development of Dahuangbaowa, China. Water, 7(6), 2771-2795. https://doi.org/10.3390/w7062771.

224. Zeng, X.T., Huang, G.H., Li, Y.P., Zhang, J.L., Cai, Y.P., Liu, Z.P., Liu, L.R. (2016). Development of a fuzzy-stochastic programming with green Z-score criterion method for planning water resources systems with a trading mechanism. Environmental Science and Pollution Research, 23(24), 25245-25266. https://doi.org/10.1007/s11356-016-7595-z.

225. Zeng, X.T., Huang, G.H., Yang, X.L., Wang, X., Fu, H., Li, Y.P., Li, Z. (2016). A developed fuzzy-stochastic optimization for coordinating human activity and eco-environmental protection in a regional wetland ecosystem under uncertainties. Ecological Engineering, 97, 207-230. https://doi.org/10.10 16/j.ecoleng.2016.09.002.

226. Zeng, X.T., Huang, G.H., Zhang, J.L., Li, Y.P., You, L., Chen, Y., Hao, P.P. (2017). A stochastic rough-approximation water management model for supporting sustainable waterenvironment strategies in an irrigation district of arid region. Stochastic Environmental Research and Risk Assessment, 31(9), 2183-2200. https://doi.org/10.1007/s00477-017-1446-4.

227. Zeng, X.T., Li, Y.P., Huang, G.H., Liu, J. (2015). A twostage interval-stochastic water trading model for allocating water resources of Kaidu-Kongque River in northwestern China. Journal of Hydroinformatics, 17(4), 551-569. https://doi.org/10. 2166/hydro.2015.090.

228. Zeng, X.T., Li, Y.P., Huang, G.H., Liu, J. (2016). Modeling water trading under uncertainty for supporting water resources management in an arid region. Journal of Water Resources Planning and Management, 142, 2. https://doi.org/10.1061/ (ASCE)WR.1943-5452.0000593.

229. Zeng, X.T., Li, Y.P., Huang, G.H., Liu, J. (2017). Modeling of water resources allocation and water quality management for supporting regional sustainability under uncertainty in an arid region. Water Resources Management, 31(12), 3699-3721. https://doi.org/10.1007/s11269-017-1696-4.

230. Zeng, X.T., Zhang, S.J., Feng, J., Huang, G.H., Li, Y.P., Zhang, P., Chen, J.P., Li, K.L. (2017). A multi-reservoir based water-hydroenergy management model for identifying the risk horizon of regional resources-energy policy under uncertainties. Energy Conversion and Management, 143, 66-84. https://doi.org/10.1016/j.enconman.2017.02.020.

231. Zhang, C., Li, M., Guo, P. (2017). An interval multistage joint-probabilistic chance-constrained programming model with left-hand-side randomness for crop area planning under uncertainty. Journal of Cleaner Production, 167, 1276-1289. https://doi.org/10.1016/j.jclepro.2017.05.191.

232. Zhang, C., Li, M., Guo, P. (2017). Two-stage stochastic chance-constrained fractional programming model for optimal agricultural cultivation scale in an arid area. Journal of Irrigation and Drainage Engineering, 143, 9. https://doi.org/10.1061/ (ASCE)IR.1943-4774.0001216.

233. Zhang, F., Tan, Q., Zhang, C., Guo, S., Guo, P. (2017). A regional water optimal allocation model based on the Cobb-Douglas production function under multiple uncertainties. Water, 9, 12 . https://doi.org/10.3390/w9120923.

234. Zhang, H., Ha, M., Zhao, H., Song, J. (2017). Inexact multistage stochastic chance constrained programming model for water resources management under uncertainties. Scientific Programming. https://doi.org/10.1155/2017/1680813.

235. Zhang, J.L., Li, Y.P., Huang, G.H., Baetz, B.W., Liu, J. (2017). Uncertainty analysis for effluent trading planning using a Bayesian estimation-based simulation-optimization modeling approach. Water Research, 116, 159-181. https://doi.org/10.10 16/j.watres.2017.03.013.

236. Zhang, M., Yang, F., Wu, J.X., Fan, Z.W., Wang, Y.Y. (2016). Application of minimum reward risk model in reservoir generation scheduling. Water Resources Management, 30(4), 1345-1355. https://doi.org/10.1007/s11269-015-1218-1.

237. Zhang, X., Huang, G.H., Nie, X. (2011). Possibilistic stochastic water management model for agricultural nonpoint 
source pollution. Journal of Water Resources Planning and Management-ASCE, 137(1), 101-112. https://doi.org/10.1061/ (ASCE)WR.1943-5452.0000096.

238. Zhang, X., Sun, A.Y., Duncan, I.J., Vesselinov, V.V. (2017). Two-stage fracturing wastewater management in shale gas development. Industrial \& Engineering Chemistry Research, 56(6), 1570-1579. https://doi.org/10.1021/acs.iecr.6b03971.

239. Zhao, Y., Chen, X., Jia, Q.S., Guan, X., Zhang, S., Jiang, Y. (2010). Long-term scheduling for cascaded hydro energy systems with annual water consumption and release constraints. IEEE Transactions on Automation Science and Engineering, 7(4, SI), 969-976. https://doi.org/10.1109/TASE.2010. 2050139

240. Zhou, X., Huang, G.H., Zhu, H., Yan, B. (2015). Twostage chance-constrained fractional programming for sustainable water quality management under uncertainty. Journal of Water Resources Planning and Management, 141, 5. https://doi.org/10. 1061/(ASCE)WR.1943-5452.0000470.
241. Zhou, X.V., Clark, C.D., Lambert, D.M., English, B.C., Larson, J.A., Boyer, C.N. (2015). Biomass supply and nutrient runoff abatement under alternative biofuel feedstock production subsidies. Agricultural Systems, 139, 250-259. https://doi.org/10. 1016/j.agsy.2015.08.002.

242. Zhou, Y., Li, Y.P., Huang, G.H., Huang, Y. (2013). Development of optimal water-resources management strategies for KaiduKongque watershed under multiple uncertainties. Mathematical Problems in Engineering. https://doi.org/10.1155/2013/892321.

243. Zhu, Y., Li, Y.P., Huang, G.H., Guo, L. (2013). Risk assessment of agricultural irrigation water under interval functions. Stochastic Environmental Research and Risk Assessment, 27(3), 693-704. https://doi.org/10.1007/s00477-012-0632-7.

244. Zhuang, X.W., Li, Y.P., Huang, G.H., Zeng, X.T. (2015). An inexact joint-probabilistic programming method for risk assessment in water resources allocation. Stochastic Environmental Research and Risk Assessment, 29(5), 1287-1301. https://doi.org/10.1007/s00477-014-1008-y. 